\title{
Service Quality of an Educational Institution Office Employees: Basis For A Proposed Training Design
}

\author{
Libh Anthony L. Limama, Fatma M. Idris, Roderick C. Rodriguez, Gladys B. Ave, \& Alberto N. Bandiola \\ The University of Mindanao, Davao Del Norte, Philippines
}

\begin{abstract}
This study aimed to determine the Service Quality of an Educational Institution Office Employees and to propose a training design based on the findings of the study. Convenient sampling technique was used in identifying the 226 respondents. Non-experimental quantitative single-variable research design was used through SERVQUAL model. Google form questionnaires were used in collecting the data. Also, mean and ANOVA techniques were used for statistical tools. Results showed very high level of service quality of Pag-IBIG Fund office employees. Accordingly, the results on service quality such as tangibles, reliability, responsiveness, assurance, and empathy were on a very high level yet still need for further enhancement as recommended in the study. Moreover, there was significant difference in the service quality of an Educational Institution office employees when analyzed by office divisions in tangibles specifically.
\end{abstract}

\section{INTRODUCTION}

\section{Rationale}

There have been clamors of poor service deliveries in the public sector. In fact, ever since the inception of the Civil Service Commission's (CSC) 8888 helpline, various agencies were flooded with complaints which were forwarded directly to the President of the Republic: Social Security System (SSS) in the release of pensions and benefits division; Land Transportation Office (LTO) in the issuance of plates and licenses division; Home Development Mutual Fund (PagIBIG Fund) in the loan grants division; Bureau of Internal Revenue (BIR) in the processing of papers; and Land Registration Authority (LRA), in the issuance of land titles (Torres, 2017).

Since COVID-19 arrived at the Philippine ground in the first quarter of 2020, national government agencies and local government units' stability were tested. Due to the massive number of people infected by the virus in a short period of time, government agencies are overwhelmed with the necessary actions resulting in struggles and challenges in terms of providing quality services to the public (Nicomedes, \& Avila, 2020).

The service industry plays an increasingly important role in the economy of many countries. In today's global competitive environment delivering quality service is considered as an essential strategy for success and survival (Parasuraman, Zeithaml \& Berry 1985; Reichheld \& Sasser, 1990; Zeithaml, Parasuraman \& Berry 1990). Even the public sectors organizations have come under increasing pressure to deliver quality services (Randall \& Senior, 1994) and improve efficiencies (Robinson, 2003). Customer needs and expectations are changing when it comes to governmental services and their quality requirements. However, service quality practices in public sector organizations is slow and is further exacerbated by difficulties in measuring outcomes, greater scrutiny from the public and press, a lack of freedom to act in an arbitrary fashion and a requirement for decisions to be based in law (Teicher, Hughes \& Dow, 2002).

Incidentally, the researchers have not come across of any study that investigates the service quality of an educational institution office employees that may become basis for training design. This study is therefore urgent so that it could fill-in the gap in the existing literatures. Exploring the factors regarding the existing problems of employees which affect the service delivery of their office may recommend for future office innovations and improvements. Furthermore, the conduct of this study is essential because there is a need to focus on the service quality of an educational institution office employees to find appropriate solutions and suitable resolution where this study dwells into.

\section{Research Objective}

This study is intended to determine the service quality of an educational institution office employees and consequently propose a training design based on the findings of the study:

1. To assess the level of service quality of an educational institution office employees in terms of:

1.1 tangibles;

1.2 reliability;

1.3 responsiveness;

1.4 assurance; and

1.5 empathy.

2. To determine the significant difference of service quality when analyzed by office division.

3. To propose a training design based on the findings.

Hypothesis

This study will test the stated null hypothesis that there is no significant difference in the service quality of office employees when analyzed by office divisions.

\section{REVIEW OF RELATED LITERATURE}

This section provides different concepts, theories and other related materials that offer a clearer structure to this study. The variable is the service quality with indicators such as 
Tangibles, Reliability, Responsiveness, Assurance, and Empathy (Parasuraman, Berry \& Zeithaml, 1991). Tangibles (appearance of physical facilities, equipment, personnel and written materials), reliability (ability to perform the promised service dependably and accurately), responsiveness (willingness to help customers and provide prompt service), assurance (knowledge and courtesy of employees and their ability to inspire trust and confidence), and empathy (caring and individual attention the firm provides its clients). Reliability is considered the vital core of service quality. Other dimensions will matter to clients only if a service is reliable, because those dimensions cannot compensate for unreliable service delivery (Berry, Parasuraman \& Zeithaml, 1994).

The following reviews are comprised of various principles and selected literatures about this subject. Several literature and studies were perused and gathered from journal readings which are believed to be relevant to the present study.

\section{Service Quality}

Primarily, service quality, according to Tjiptono (2008), is a measurement in what way a service meets the expectation of the consumer. He further added that coordinated with the definition, in achieving the quality, the needs and demands of customers and accuracy in delivering the message must be fulfilled to meet the expectation of clients. Thus, the quality of service was influenced by two main factors which are the expected service and the perceived service. He also discussed that when the perceived service is being levelled with the expected service, then the quality is perceived positively or well. He described that when the expected service is less than the perceived service, the service quality is perceived as ideal quality. Conversely, when the expected service is more than the perceived service, then the quality of service is perceived as poor or bad.

Further, Parasuraman, Berry and Zeithaml (1988) stated that the service quality can be explained as a general judgment like attitude regarding the service and commonly accepted as the origin of overall client satisfaction (Zeithaml and Bitner, 1996). Additionally, it was defined by Parasuraman et al (1988) that service quality is the ability of the organization to meet or to surpass the expectations of clients. It is the distinction among customer expectations of service and perceived service as defined by Zeithaml et al (1990). Moreover, they also described that the comparisons by expectations of clients with their perceptions of delivered services by the suppliers will result to perceived service quality. Furthermore, Parasuraman, Zeithaml, and Berry (1985); Lewis and Mitchell (1990) explained that when performance is less than expectations, then satisfactory is more than perceived quality and thus the dissatisfaction of clients occurs.

The Local Government Units (LGU) claimed that in spite structural reforms poor government service is still evident (Mendoza, 2011). These poor government services vary from inaction on submitted requests or applications, slow processing of papers, snub civil servants, irritable employees, overcharging of fees, and presence of so-called "fixers" who promise quick service in exchange for cash (Torres, 2017). These scenarios make customers impatient and eventually dissatisfied on the services (Social Security System Davao City Annual Report, 2011).

Also, the discussions to the issues of services especially on the public organizations like Pag-IBIG Fund Davao are very essential to deal with, which is significant on the organizational development and improvement. In the study of Head and McCoy (1991), he stressed that Public service organizations are now being asked to redesign the way services are delivered with a commitment and to improve the availability and quality of those services. In the Philippines, Manasan (2007) suggest that decentralization assures better local services for an improved quality of life. The importance of quality service delivery on the Philippine Governmentowned and Controlled Corporations (GOCCs). Ballesteros and Egana (2013), for instance, found the advantages of an efficient and effective government service, otherwise customers will be dissatisfied with the agency and rant with more complaints.

The first indicator is Tangibles, Parasuraman et al (1985) described tangibility as the appearance of equipment, physical facilities, written materials, and personnel. Ananth, Ramesh, and Prabaharan (2010) defined tangibility as modern looking equipment, physical facility, employees are well dressed and materials are visually appealing in their study of private sector banks.

The second indicator is Reliability which vary on performing services right the first time; provide services at the promised time and maintaining error-free record; handling customers' services problems. Moreover, Parasuraman et al. (1988) identified reliability as the most important factor in conventional service. Thenceforth, reliability also involves of accurate record; accurate order fulfilment; accurate in billing; accurate quote; keep services promise; accurate calculation of commissions. He further mentioned that reliability is the most important factor in front line services (Yang \& Fang, 2004).

Besides, Bowen (1986) illustrates that in the presence of service producer and customer, unlike tangible products, services are produced and consumed. On the part of employees and clients during the process of service delivery the manifestation of human as part of the process significantly proliferate the chances of error. The said error is because of the intangible behavioural processes that are hard to control and monitor. Conversely, the focus on the service clients' perceived service quality is through extensive amount of research on service quality and relatively the investigation with the factors that influence the service behavior of employees regarding with the service quality delivery has inadequately paid attention (Parasuraman et al, 1988; Carman, 1990; Parasuraman et al, 1991; Babakus \& Boller, 1992; Cronin \& Taylor, 1992; Babakus \& Mangold, 1992). 
The third indicator is Responsiveness, as per Parasuraman et al (1985) is the willingness or readiness of employees to provide services where it involves timeliness of services. Likewise, it involves understanding wants and needs of the clients, individual attention given by the staff, attention to problems and customers"e safety in their transaction, convenient operating hours (Kumar, Kee \& Manshor, 2009).

Additionally, Surprenant and Solomon (1987) affirmed that service encounters are human interactions. They recommended that service provider and clients have responsibilities after and during service encounter which are based on interpersonal interactions between clients and organizations. Service quality in all service encounters is thus intrinsically affected by the perspectives of both the service provider and the service receiver. Correspondingly, Czepiel (1990) established that it is important to include the perspectives of both the receiver and the provider in the researches about service quality. However, there has been a constrained on most of the research on the service quality construct into one perspective which is that of the service receiver (Parasuraman et al, 1988; Guerrier \& Deery, 1998). In service encounters a few have considered interactive features of service quality and applied dual perspectives (Tam \& Wong, 2001; Chow-Chua \& Komaran, 2002; Dedeke, 2003; Svensson, 2004; Svensson, 2006).

Moreover, Schneider and Bowen (1985) expressed that the behaviors and attitudes of the interacted employees can influence the perceptions of clients with service quality because service delivery happens during the interaction between clients and employees. Further, Beatson, Lings and Gudergan (2008) discovered that perceived employee commitment, perceived employee satisfaction, and perceived employee loyalty substantially influence the perceived product quality and the perceived service quality. It was further deliberated by Zeithaml and Bitner (1996) that contact employees symbolize the organization and has direct impact with client satisfaction where they play the task of marketers. Whether recognized or not, service employees perform marketing tasks. Their good performance with their functions will be advantageous to the organizations while their poor performance will result to detriment of the organization. Likewise, Bettencourt and Gwinner (1996) described that front-line employees can modify not only the services of the organization, but also their strategies on delivering those services.

Parasuraman et al (1988) suggested that customer expectations are what the customers think a service should offer rather than what might be on offer. Zeithaml et al (1990) identified four factors that influence customers' expectations: word-of-mouth communications; personal needs; past experience; and external communications. A gap is created when the perceptions of the delivered service is not as per the expectations of the customer. This gap is addressed by identifying and implementing strategies that affect perceptions, or expectations, or both (Parasuraman et al, 1985; Zeithaml et al, 1990).
The fourth indicator is Assurance, Parasuraman et al (1985) explained assurance as courtesy and knowledge of employees and their ability to inspire confidence and trust. As per Sadek, Zainal, Taher and Yahya (2010) in British banks assurance defined as friendly and polite staff, interior comfort, provision of financial advice, knowledgeable and experienced management team, and eases of access to account information.

Subsequently, the client reactions, actions, and other characteristics are three things that intensively influence the front-line service personnel's mannerisms and actions (Solomon et al, 1985; Matzler, Fuchs \& Schubert, 2004). Clients basically establish their reactions of the level of service provision of organization based on their interactions and encounters with front-line employees. Thus, those employees who are directly involved in the front-line service delivery are those who can provide essential information that could help in improving services. Front-line employees are full of knowledge about the strengths and weaknesses of the services in organizations through their direct interactions with the clients which is very important form of feedback that can be utilized by the organizations in making decisions to better serve clients. Based on the researched by Schneider and Bowen (1985), it has established positive correlation between the attitudes of employees and those of clients, which includes the perceptions of service quality of employee and client.

Lastly, as per Paulrajan and Rajkumar (2011) services are forms of attitude which are related to satisfaction and lead to consumers' preferences. From the perspective of the organization, there is a desire to survive and compete in a global environment. Base on the clients' perspectives, there is a desire for better service quality.

The last indictor is Empathy, Parasuraman et al (1985) identified empathy as the individual attention and caring which the organization provides with its clients. It consists giving clients individual attention and employees understanding to the needs of their clients and convenient business hours. Moreover, Ananth et al. (2010) stated empathy in their study as giving individual attention; giving personal attention; convenient operating hours; understand client's specific needs and best interest in heart on private sector banks.

Services of public sector are responsible and accountable to communities and citizens as well as to its clients. Numerous researchers have dealt with service quality in public services (Wisniewski, 1996; Rowley, 1998; Wisniewski, 2001; Brysland \& Curry, 2001). Likewise, Brysland and Curry (2001) specified that the literature obviously supported the use of SERVQUAL (Service Quality Model) in the public organizations. As said by Gowan, Seymour, Ibarreche, and Lackey (2001), public organization service provision is very complex for it is not merely just meeting the expressed needs, but of realizing the unexpressed needs, establishing priorities, allocating resources and justifying and accounting in public things that has been accomplished. Also, Caron and Giauque 
(2006) draw attention to the new professional issues which occurred from the latest tools and principles enthused by the shifting of new management in public.

Subsequently, the quality of service stipulated by a public university health clinic was also measured by Anderson (1995). The five-dimensions of SERVQUAL (Parasuraman et al, 1988) represented using 15 statements; she carefully assessed the service quality postulated by the clinic at the University of Houston Health Center. It was found out that the patients were dissatisfied with the five dimensions of SERVQUAL in general. Patients' manifested their highest dissatisfaction with assurance. In contrast, it was exhibited that tangibles and empathy have the lowest level of dissatisfaction. In the study of Wisniewski (2001) using the SERVQUAL approach, there was an assessment with the customer satisfaction in the public sector throughout the span of Scottish Councils Services. The results in the library services shows that the clients' expectations were not met for the analysis of gap scores revealed that reliability and tangibles had negative gaps. Conversely, the clients' expectations were suggested basically exceeded by the service provided where the assurance and responsiveness revealed positive.

Afterwards, in the study of Donnelly et al (2006), they explored the SERVQUAL approach application in accessing the service quality of Strathclyde Police in Scotland. The survey obtains the clients' expectations of excellent police services and compares these with their perceptions of the delivered services by the Strathclyde Police in Scotland. It was also reported on the study a similar SERVQUAL survey of police officers in Strathclyde where it was examined how well the force understand its clients' expectations and how well its internal processes support the quality services delivery in the department of police. The result revealed in the area covered by the force the Strathclyde Police appeared that they had good understanding with the service quality expectations of their clients through the elected councilor's response. Thus, for improvement in the service quality performance there is always a room for improvement both from clients' perspectives and through and across the police force attention to the compliance with, and definition of, service quality standards.

Moreover, a research accomplished by Agus, Barker and Kandampully (2007) identified clients' perceptions and management of practices of service quality in the public sector of Malaysia. It is necessary to observe that the SERVQUAL model focused on identifying gaps between actual delivery and expectations but merely focused on actual service delivery perceptions. In the ten dimensions of service identified by Parasuraman et al (1985) they used only nine. Their study focused on the management and clients' perceptions disregarding the front-line employees' perspectives. Therefore, most of the studies up to present have examined the European and US public sector service quality, while several recent studies surveyed the quality of service in developing countries.
Furthermore, Zamil and Shammot (2011) rationalized that government large organizations have clients which are the business sector, citizens, private and public employees. The clients give their assessments to the delivered performance by the Government through departments, agencies, and ministries that provides the services and information to the public. Correspondingly, Nor, Khalid, Razali and Ramli (2010) affirmed that in building a good credibility and reputation in the community, the significant contribution of customer services in public sector organizations are the primary necessary factors. Public complaints of poor service, poor physical facilities and long queues are not adequate to affect the image and the service quality level in the public sector.

As a final point, it was suggested by Ilhaamie (2010) that the service quality performance on service quality of governmental organization is of the major dimension in public sectors as the output of an organizations are public services. Shammot (2011) further asserted that traditionally, the government is not considering the citizens as their clients but as the people who will pay for the services provided, thus it will run smoothly and properly. Societies are the clients and their satisfaction must be credited. There must be an understanding with the Public employees that they will gain their salary by effectively serving the public.

Then, De Leon (1999) demonstrated public utility as a business organization which commonly supplied the public with several services and commodities, such as water, gas, electricity, telegraph, telephone, or transportation service. Its characteristic is the devotion of private property to such use that the public generally or that part of the public who has been served and accepted the service. Relatively, Zeithaml, Berry and Parasuraman (1996) conducted a study where they emphasized that the delivered services by the public in real time, service performances gap's closing were profoundly dependent on the strategies of human resource. The effective and successful executions of such strategies begins with the nurturing and development of a genuine service cultures in which the increase for good services exist, and where good services are internal as well as ultimate.

Thenceforth, the officials of the organizations must learn to utilize the power of internet which will result to positive delivery of services that will lead to positive observations with regards to the government (Bowie, 1996; Fountain \& OsorioUrzua, 2001). Hence, the efficiency of employees on the usage of internet and electronic technology can affect the good service delivery of an organization. Gore (1993) further added that e-government assured to directly deliver services into the homes of citizens. If all the services can be operated through online, employees work efficiency can be observed and it could lessen the issues faced by the organization with the service delivery. Consecutively, a new technology in Karnataka has been launched about a mobile-based service which offers services that are currently available via internet (Mittal, Gandhi \& Tripathi, 2010). 
Consequently, matching workers and tasks are beneficial to both the quality and efficiency of service delivery (Metters \& Vargas, 2000). In addition, Greene (1995) distinguished higher levels of education as the instrument to obtain information easier about how low quality of service delivery and corruption can be reported. Further, Joseph, McClure and Joseph (1999) stated that most of the clients now a day significantly prefer technology-based service delivery than employee and client interface. It was also discussed that in reducing employee and client interface, service sectors have to use technology for standardization of services.

Moreover, Dabholkar (1994) concurred that through the discussion on how the technology-based services will create new delivery options of services that were accessible to the organizations which made the participation of clients broadly possible. This was supported by Joseph et al (1999), where they affirmed that the clients believe to have positive perspectives on technology-based quality of services because they considered that technology is more efficient and can deliver faster services than employee.

Additionally, quality service delivery revolves around the idea that quality should be judged on the assessments of the consumers or users of the services. The making of quality as conceptualized in the services literatures is based on the perceived quality. As elaborated by Zeithaml (2007) and Zammuto (2006), perceived quality is defined as the client's judgment about an entity's overall delivered services to the end users. Similarly, Chrisman (2007) concluded that perceptions of service quality is the result from comparing expectations prior to receiving the service, and their actual experience of the service. Likewise, Rowley (2006), added that perceived quality is also seen as a form of attitude related to, but different from satisfaction which is the result of comparing expectations with perceptions of performance.

Then, perceived service quality could be the product of the evaluations of several services encountered specifically by the employee. These could range from the office staff, tutors, lecturers, head of departments. Thus, Zammuto (2006) supposed that if an organization fails to meet the client's satisfaction and expectations, the services will be judged as poor quality. If an organization regularly provides services at a level that exceeds client's expectations, the service will be evaluated as high-quality service delivery.

Accordingly, as mentioned by Baron (2006), Requisite encounters which means to enable the students to fulfil their study obligations; Acceptable encounters, which means that the students acknowledge as being desirable but not during their course of study; and Functional encounters, which is an encounter of a practical or utilitarian nature. Those are the three main criteria for students' satisfaction with the services. Also, Gronroos (1988) commented that the quality of services is made up of dimensions: the technical quality of the outcome, which is to differentiate among quality associated with the processes of service delivery; functional quality of the encounter, which is to associate with the quality of the outcome of services; and, the company image, which is judged by the consumer after the performance of the services. Conversely, tangibility, responsiveness, reliability, competence, courtesy, access, communication, credibility, security, and understanding were the ten determinants of service quality that can be generalized to any types of services (Parasuraman, Zeithaml \& Malhotra, 2005).

Consequently, Azar and Khan (2012) mentioned the importance on the scores of quality services in higher education. It was realized that the performance on academic has been ranked first then by programmed issues, career opportunities, cost/time, location, physical aspects, and others. Several researches on service quality in higher education strongly accentuated that the academic performances have given more emphasis than administrations, which concentrates on effective courses delivery mechanisms and the quality of courses and teachings (Gilbert, 2003).

Further, quality services are the generally complex prerequisite in sustaining and establishing satisfying relationships with valued clients. In this way, the link between service quality and client satisfaction has arose as a topic of strategic and important concern Cronin (2007). Thus, profound focus on understanding the determinants and antecedents of the satisfaction of customer had an extremely high value for organizational services in a competitive environment (Lassar, Manolis \& Winsor, 2000). Currently, electronic governance was addressed to improve the delivery of services and the responsiveness to the public (Gore, 1993). Likewise, Parasuraman et al (1991) enumerates six dimensions of service quality which are tangibles, reliability, responsiveness, assurance, and empathy which is very useful in finding satisfactory results concerning the employees' problems.

Furthermore, as stated above, Strong and Harder (2009) concurred that modern physical environment, salary and wage, office services, employment, occupational position, sufficient benefits and income, and rewards are some of the employees existing problems that affects their job motivation. Moral rewards, job enrichment, financial rewards, development of creativity in job, and advancement and development in job are factors affecting the motivation of employees. Besides, the appropriateness of working conditions, the efficiency of training equipment, promotion and growth, and income are necessary on the effective job motivation of employees (Celikoz, 2009).

Moreover, Jalalian, Sayadi, and Shabankareh (2014) introduced that suitable working conditions and high salary and benefits are related to the existing problems of employees regarding with the office service delivery of the organization. The connotation between job motivation and efficiency level shows that demotivation affects the decreasing of the employees' efficiency in the organization. It was traced in a research which suggests that the motivation of employees was affected by their environment. They also discussed that discrepancy and uncertainties in the service delivery system 
requires design of staff, technology, and facilities in the production system. Employees on different organizations are also facing different issues with regards to the service delivery of the organization. Further, it was enumerated the factors that affect the job motivation of employees on the office service delivery which are the following: Punishment and persuasion, achievements on works and jobs, external anticipations, mental interests, training opportunities, honor and status of job, freedom, human relations, etc.

In addition, based on a study by Mahal, Srivastava, and Sanan (2000), they reveal that through decentralization of public service delivery on essential public services is positively correlated with human development. Consequently, several studies showed that lack of job independence, lack of job security, shortage of wage and salary, long working hours and insufficient resources are described as factors on the disappointment and demotivation of employees that affect office service delivery (Appleton et al, 1998).

Subsequently, the Deolalikar and Jha (2013) stressed that the delivery of high-quality public services is an essential element of inclusive development. A public services system providing essential food, health services, and medical care to vulnerable sections of the population can bring the essentials of livelihood within easy reach of people whose lives may remain otherwise untouched by income growth. In addition, Garcia-Zamor (2015) stated that, the rise of government's responsibility to the people in the form of providing what is viewed as necessary services has been a central focus in the field of Public Administration.

Thereafter, Tamrakar (2010) mentioned that Public Service Delivery is defined as a set of institutional arrangements adopted by the government to provide public goods and services to its citizens. Somewhat, Ooesterom et al. (2007) explained that the public sector is collectively the world's largest services provider. Any incremental improvements in public services positively impacts millions of people. The first step in delivering the clients promise is to know the clients and their needs. Further it was stressed that work efficiency is often boring and uninteresting, scientific managers believed that for the workers to be able to make sacrifices they are interested in high-paying and stable jobs, they are into high wages.

Thenceforth, van Graan and Ukpere (2012) noted that there is an increasing demand to evaluate the impact of programs and policies in the public services because public services of organizations are constantly under pressure from the public to provide efficient and quality services. Impact evaluation will enable organizations in determining and adopting best practices to improve delivery of services and considered as a management tool for improving delivery of services within organizations, particularly in the public sector.

The SERVQUAL model suggests that clients evaluate the quality of services on five distinct dimensions which are reliability, responsiveness, assurance, empathy, and tangibles. The SERVQUAL instrument consists of twenty-two (22) statements for assessing consumer perceptions and expectations regarding the quality of a service. Perceived service quality results from comparisons by consumers of expectations with their perceptions of service delivered by the service providers (Zeithaml et al, 1990). It can be argued that the factor underpinning the delivering of good perceived service quality is actually meeting the expectations of the clients. Thus, excellent service quality is exceeding the clients' expectations. Further, Zeithaml and Bitner (2000) suggested that customer expectations are beliefs about a service that serve as standards against which service performance is judged.

Subsequently, Parasuraman et al (1988) proposed that expectations of the clients are what the clients think a service should offer rather than what might be on offer. Relatively, Zeithaml et al (1990) identified four factors that influence clients' expectations which are word-of-mouth communications, personal needs, past experience, and external communications. Gap is created when the perceptions of the delivered service is not according to the expectations of the clients. This gap is addressed by identifying and implementing strategies that affect perceptions, or expectations, or both (Parasuraman et al, 1985; Zeithaml et al, 1990).

Furthermore, Parasuraman et al (1988) stated that SERVQUAL was designed to be applicable through a wide range of services and the format could be adapted to fit specific needs, and that it would be most valuable when used to track services quality trends occasionally. They stated that the SERVQUAL model could be extended to determine gaps in quality and could therefore be used as a diagnostic tool to allow management to detect service quality deficits. The gap score is measured by the perception statements deducted from the expectation statements. If any gap scores turn out to be positive, then this suggests that expectations are actually being surpassed. This permits service managers to evaluate whether they need to re-deploy resources to areas of deficit (Wisniewski, 2001).

In summary, the cited literature and studies which include readings, research results and findings were related to service quality of office employees. Indicators of service quality are Tangibles, Reliability, Responsiveness, Assurance, and Empathy which were assessed accordingly. These materials helped in further understanding how service quality of PagIBIG Fund office employees differs from each division. This was used as guide and sources in the presentation of the results and discussion of the study.

\section{THEORETICAL FRAMEWORK}

This study was mainly based on the proposition of Parasuraman, Berry and Zeithaml (1988) that service quality is measured by identifying the gaps between customers' expectations of the service to be rendered and their perceptions of the actual performance of the service. Servqual is based on five dimensions of service: tangibles - the physical surroundings, represented by objects (e. g., interior 
design) and subjects (e. g., the appearance of employees); reliability - the service provider's ability to provide accurate and dependable services; responsiveness - a firm's willingness to assist its customers by providing fast and efficient service performance; assurance - features that give customers confidence (e. g., the firm's specific service knowledge and polite and trustworthy behavior from employees); empathy - the firm's readiness and ability to provide each customer with personal service.

Then followed by Agus et al (2007), where they discussed that it is important to note that whereas the SERVQUAL model focused on identifying "gaps" between expectations and actual delivery, their model focused only on perceptions of actual service delivery. Subsequently, the proposition of Gowan et al. (2001), who stated that service provision is more complex in the public sector because it is not simply a matter of meeting expressed needs, but of finding out unexpressed needs, setting priorities, allocating resources and publicly justifying and accounting for what has been done. In addition, Caron and Giauque (2006) pointed out that public sector employees are currently confronted with new professional challenges arising from the introduction of new principles and tools inspired by the shift to new public management.

The last proposition was based on Zamil and Shammot (2011), who explains that the government, as large organizations, has customers and the customers are the citizens, businesses sector, public and private employees. Government through agencies, departments, and ministries provides information and services for each customer group and as a result, the customers give their assessment to the performance delivered. Relatively, Nor et al. (2010) states that public sector organizations, which provide customer service is one of the important factors that gives significant contribution to build good reputation and credibility in the community. Public complaints of long queues, poor service and poor physical facilities are not adequate to affect the image and the quality level of service in the public sector.

\section{Conceptual Framework}

The concept of the study was illustrated in Figure 1. The input variable is service quality, which has the following indicators: Tangibles, Reliability, Responsiveness, Assurance, and Empathy (Parasuraman et al,1991). Tangibles refers to physical facilities, equipment and appearance of personnel; reliability refers to ability to perform the promised service dependably and accurately; responsiveness refers to willingness to help customers and provide prompt service; assurance includes competence, courtesy, credibility and security refers to knowledge and courtesy of employees and their ability to inspire trust and confidence; and empathy includes access, communication, understanding the customer refers to caring and individualized attention that the firm provides to its customers.

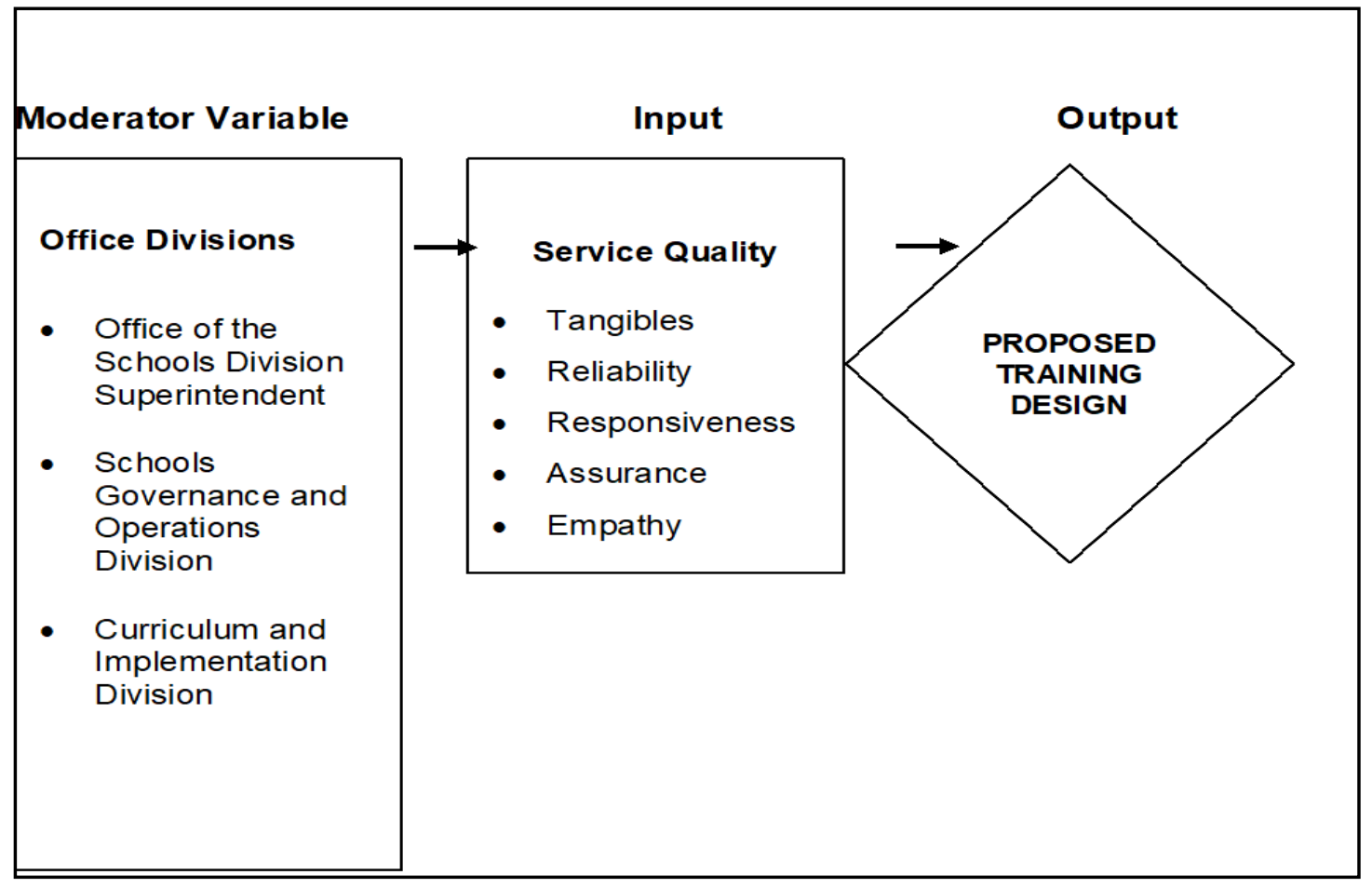

Figure 1: Conceptual Framework Showing the Variables of the Study

The study presented a training design for the basis of the findings. The moderating variable is Office Divisions, which includes the following: Office of the Schools Division
Superintendent, Schools Governance and Operations Division, and Curriculum Implementation Division. 


\section{Significance of the Study}

Service quality is very essential in the global scale (Bowen, 1986) services are produced and consumed in the presence of service producer and customer, unlike tangible products. During the process of service delivery, the manifestation of human as part of the process significantly proliferate the chances of error on the part of employees and clients. The said error is because of the intangible behavioral processes that are hard to control and monitor.

The significant contribution and sharing of best practices of the selected educational institution office employees and clients in this study was essential not only for the educational institution but also for other government agencies which will help them to improve quality services and the efficiency of the employees' performance. This makes organizations realize that there is a problem and a need for solution which this study provides.

In addition, the literature review of this study will help the government office heads to take actions on how to help employees to improve quality services on the educational institution. The insights and realizations that will be gathered from the educational institution office employees and clients will be beneficial for the Human Resource Department and Technical team which will help them understand the service quality issues that would affect the organization. Moreover, the study also provides related studies that are necessary for the government office heads to read and apply for the development of the public office services.

Lastly, the main beneficiaries of this study are the employees who are the one who performed the functions in the educational institution in Panabo City and the clients to receive better services. Furthermore, the study provides future discussions and suggestions that would help them to solve issues on quality services through training design. For future researchers, they may explore more about redesigning and restructuring of government offices for the progress of the organizations because government offices in the Philippines are too static.

\section{Definition of Terms}

Service Quality: This was enumerated in five dimensions which are tangibles, reliability, responsiveness, assurance, and empathy which is very useful in finding satisfactory results concerning the office employees' service problems. These five dimensions were explored and analysed by the researchers in this study.

Training Design: This was used as the output of the study. Also, this will be established based on the results of the study. This was proposed for the basis of the findings.

\section{METHOD}

This chapter contained the brief explanation of the methods employed in this study such as the research design, research locale, population and sample, the research instrument, the data collection, and the statistical tools.

\section{Research Design}

This study used a quantitative descriptive research design using single variable. A single variable research also known as single case experiments is commonly used in the various fields of special education and counseling.

Subsequently, the systematic and detailed analysis of individual that is provided through single-variable research methods has drawn researchers not only from special education, but also from a growing group of scholarly disciplines, with over forty-five professional journals now reporting single-subject research (Hollon, Miller \& Robinson, 2002).

This form of inquiry has suppositions about testing theories deductively, building in protections against bias, controlling for alternative explanations, and being able to generalize and replicate the findings. Since the study assessed the level of service quality of an educational institution office employees in terms of tangibles, reliability, responsiveness, assurance, and empathy, hence the quantitative survey method was the most appropriate to use.

Moreover, descriptive research reports evidences about a situation (Hull, 2007) and is primarily concerned with finding out what is the situation or what is happening. A descriptive research design was chosen because it is used to answer descriptive research questions such as "What is happening? How is something happening? Why is something happening?" (Lauer, 2004).

One type of descriptive research is a survey method. The researchers used survey method in gathering the data of an educational institution office employees. According to Gay, Mills, and Airasian (1996), survey research can be used to gather information about a group's beliefs, attitudes, behaviors, and demographic composition. Furthermore, the questionnaires were validated to generate a comprehensive research tools. Check and Schutt (2012) discussed that a welldesigned survey can enhance our understanding of just about any educational issue. Through a survey of service quality, this study sought to determine the service quality of the educational institution office employees which became the basis for creating a training design.

Thus, the researchers used the SERVQUAL which was designed to be applicable across a broad spectrum of services and the format was adapted to fit specific needs, and was used in tracking service quality trends periodically. The used of the SERVQUAL model was extended to measure gaps in quality and was used as a diagnostic tool in enabling management on 
identifying service quality shortfalls. This allows service managers to review whether they need to re-deploy resources to areas of underperformance (Wisniewski, 2001).

Research Locale
This study was conducted in Panabo City particularly on the front-line services of the three Divisions (Office of the Schools Division Superintendent, Schools Governance and Operations Division, and Curriculum and Implementation Division) of an educational institution in Panabo City, Philippines

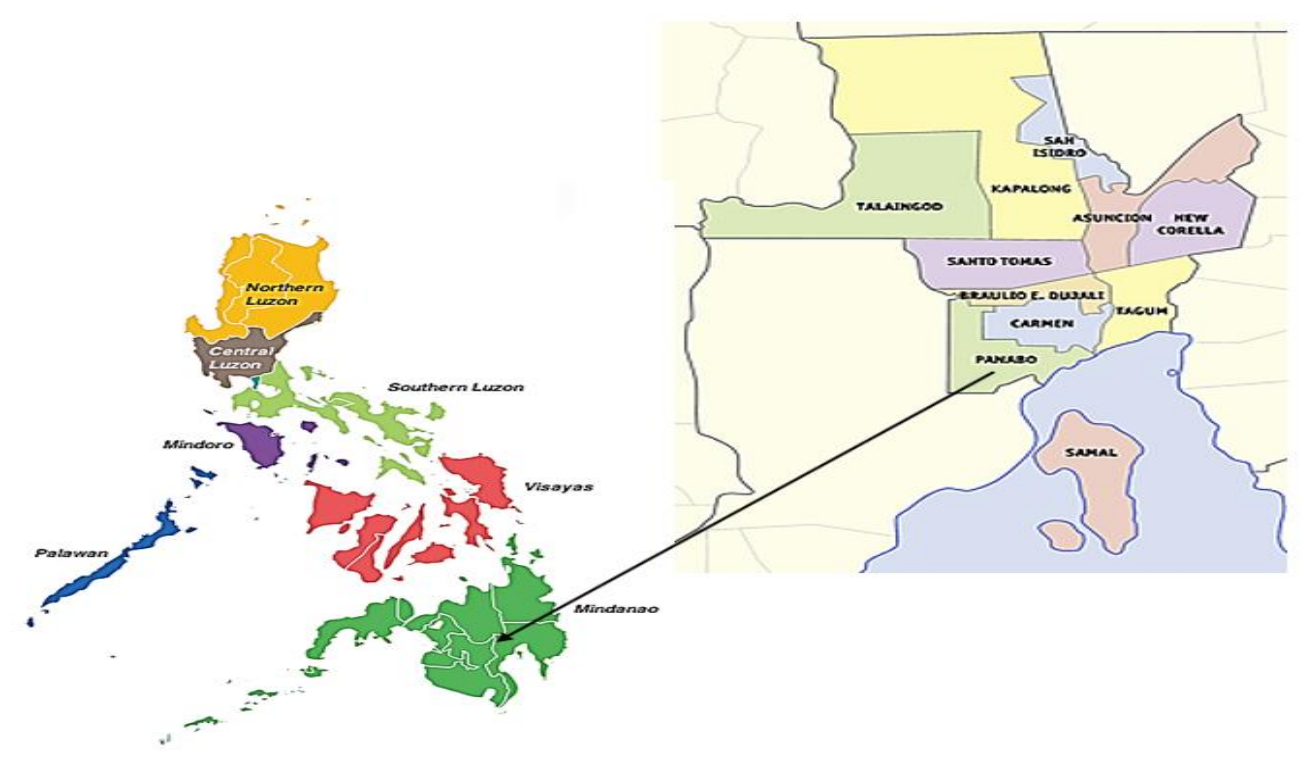

Figure 2: Philippine Map Showing the educational institution in Panabo City.

The Offices caters various clients with their specific transactions.

\section{Population and Sample}

Convenience sampling method was used in determining the respondents who were included in this study. Convenience Sampling (also known as availability or accidental sampling) is a form of sampling that involves the researchers selecting the most readily available respondents, regardless of characteristics, until the required sample size had been achieved. Convenience sampling involves obtaining responses from those people who were available and willing to take part. The study included convenient clients of the Divisions (Office of the Schools Division Superintendent/OSDS, Schools Governance and Operations Division/SGOD, and Curriculum and Implementation Division/CID) of an educational institution in Panabo City.

There were total of 226 respondents who answered the questionnaires. Below is the Profile of respondents. Most of the respondents who willingly answered the questionnaire were the clients of an educational institution in Panabo City Division regardless of age, gender, and civil status. The respondents were inquiring, updating, and monitoring about their transaction for approval and of various documents. The respondents answered through their perceptions and expectations regarding with the service quality of the educational institution Office employees using modified and contextualized questionnaire thru google form which was sent using social media messengers and the various group chats of the clients within Panabo City. The researchers explained the purpose of the study and the importance of their participation on the study. The researchers also assured the respondents of the full confidentiality of their responses.

There were a total of two hundred twenty six respondents who answered the questionnaire. In the OSDS there were 58 respondents that is twenty-six percent of the total respondents. Subsequently, in the SGOD there were 94 respondents that is forty-two percent of the total respondents. Lastly, in the CID the number of respondents who conveniently answered the questionnaire were 74 which is thirty-two percent of the total respondents.

\section{Profile of Respondents}

\begin{tabular}{|c|c|c|}
\hline $\begin{array}{c}\text { Indicator } \\
\text { Division Office }\end{array}$ & F & Percentage \\
\hline $\begin{array}{c}\text { Office of the Schools Division } \\
\text { Superintendent }\end{array}$ & 58 & 26 \\
\hline $\begin{array}{c}\text { Schools Governance and } \\
\text { Operations Division }\end{array}$ & 94 & 42 \\
\hline $\begin{array}{c}\text { Curriculum and Implementation } \\
\text { Division }\end{array}$ & 74 & 32 \\
\hline TOTAL & 226 & 100 \\
\hline
\end{tabular}




\section{Research Instrument}

The study used survey questionnaires thru google form in gathering information from the respondents. It is a researchbased type of a questionnaire. The introductory part of the questionnaire was the consent letter for the respondents to participate on the study. The questionnaire was composed of five major dimensions of service quality which are: Part A of the questionnaire contained four item statements pertaining to tangibles; Part B of the questionnaire contained four item statements pertaining to reliability; Part $\mathrm{C}$ of the questionnaire contained four item statements pertaining to responsiveness; Part D of the questionnaire contained four item statements pertaining to assurance; and Part $\mathrm{E}$ of the questionnaire contained four item statements pertaining to empathy.

The respondents answered the questionnaires by checking the desired number that corresponded to their personal knowledge and experience stipulated in each item in the questionnaire. A five-point Likert scale allows the respondents to express how likely they agree or disagree with the statement. For confidentiality of the respondents, the collected responses from the google form was kept with utmost confidentiality and after tabulating all the data needed by the statistician thru a form of a tally sheet the questionnaire or the google from with the responses of the clients will then be deleted to assure the confidentiality and safety of the respondents.

Below are the Likert's scales that was used in the interpretation of responses in the questionnaire.

In assessing the level of Service Quality of the educational institution office employees, the following Likert scales will be used:

\begin{tabular}{|c|c|c|}
\hline $\begin{array}{c}\text { Range of } \\
\text { Means }\end{array}$ & $\begin{array}{c}\text { Descriptive } \\
\text { Levels }\end{array}$ & Interpretations \\
\hline $4.20-5.00$ & Very High & $\begin{array}{l}\text { This means that the service quality of } \\
\text { the educational institution office } \\
\text { employees is always manifested by the } \\
\text { clients. }\end{array}$ \\
\hline $3.40-4.19$ & High & $\begin{array}{l}\text { This means that the service quality of } \\
\text { the educational institution office } \\
\text { employees is oftentimes manifested by } \\
\text { the clients. }\end{array}$ \\
\hline $2.60-3.39$ & Moderate & $\begin{array}{l}\text { This means that the service quality of } \\
\text { the educational institution office } \\
\text { employees is sometimes manifested by } \\
\text { the clients. }\end{array}$ \\
\hline $1.80-2.59$ & Low & $\begin{array}{l}\text { This means that the service quality of } \\
\text { the educational institution office } \\
\text { employees is seldom manifested by the } \\
\text { clients. }\end{array}$ \\
\hline $1.00-1.79$ & Very Low & $\begin{array}{l}\text { This means that the service quality of } \\
\text { the educational institution office } \\
\text { employees is never manifested by the } \\
\text { clients. }\end{array}$ \\
\hline
\end{tabular}

\section{Data Collection}

These were the procedures in gathering the data for this research. First, the questionnaire was transcribed in the google form to easily conduct and disseminate the study following the IATF protocols of the COVID-19. Then, the final questionnaires was sent to all respondents thru google forms by means of social media messengers and group chats. The respondents was assured with utmost confidentiality of their responses. The researchers secured that the respondents understood the questionnaires and the purpose of the study. Also, the researchers guaranteed that the respondents read the consent letter on the introductory part of the questionnaire.

The researchers will made clear to the respondents the questions and the purpose of the study. Next, the responses in the google form was observed and summarized to made sure the attainment of the number of respondents needed for the study. The researchers kept the responses with utmost confidentiality thru restricted access of the google form in the google drive where their profile characteristics and responses will be secured. The researchers will also explain the importance of their cooperation in the study and its beneficial contribution in the improvement of the services of the office which was also very beneficial in their perspective.

Results of the survey questionnaire thru google form was tabulated using Microsoft excel collate. For confidentiality of the respondents, accomplished questionnaires thru google form was deleted from the google drive.

\section{Statistical Tools}

Mean. This was used in measuring the level of service quality of an educational institution office employees.

ANOVA. This was applied in determining the significance of the difference of service quality when analyzed by office division.

\section{Ethical Consideration}

Ethical consideration is an important and crucial factor in research. Walker (2007) stresses that in attaining ethical consideration, it is a must for every researcher to consider the confidentiality of the respondents in the process of the study. $\mathrm{He}$ emphasized that important ethical issues such as confidentiality, respect to respondents' opinions, and integrity was given focus by the researchers and failure to address such issues means putting at risk the rights of research respondents. Respondents in this study will not be forced; their decisions on the willingness to participate on the study will be highly respected.

The data was privately and securely collected from the responses of the respondents in the google form and the deletion of the accomplished google forms was also done. The consent letter was indicated in the questionnaire and the researchers were always open for any inquiries with regards to their participation in the study. There were no risks involved for the result of this study will help improve services in the future. The researchers assured that the study will not be copied. The stated theories and information was paraphrased and properly cited. The information and the results in the study will not be intentionally misinterpreted and no making up of data. Accuracy of the data in the conclusion and 
consistency with the existing literature was observed in the manuscript.

There was no misinterpretation of data to fit a certain model or theoretical expectation and the study avoided exaggerations. It was assured that there is no trace of conflict of interests; the respondents are free to quit or stop on answering the questionnaire anytime. Notably, Johnson (2007) mentioned that the following protection of human rights shall be considered: right to self-determination, right to anonymity and confidentiality, right to privacy and dignity, right to fair treatment and right to protection from harm.

Aside from the above-mentioned human rights protection, special consideration will be taken cared of for those who participated in sensitive research especially those which might involve personal experiences or issues they considered as taboo.

\section{RESULTS}

This chapter presents the result of the study in tabular and contextual form.

\section{Level of Service Quality of an educational Institution Office Employees}

The level of service quality of an Educational Institution office employees is shown in Table 1. The results revealed that the overall mean was 4.41 with a descriptive level of Very High. This means that the service quality of an educational institution office employees is always felt/manifested.

The result further revealed that assurance obtained the highest mean 4.48 with descriptive level of Very High. This was followed by responsiveness with a mean of 4.45 with descriptive level of Very High. Empathy and reliability followed next with a mean of 4.43 and 4.35 respectively, both with descriptive levels of Very High. Lastly, tangibles got the lowest mean of 4.33 with a descriptive level of always felt/manifested.

Table 1: Level of Service Quality of an Educational Institution Office Employees

\begin{tabular}{|c|c|c|c|}
\hline Indicator & SD & Mean & $\begin{array}{c}\text { Descriptive } \\
\text { Level }\end{array}$ \\
\hline Tangibles & 0.16 & 4.33 & Very High \\
\hline Reliability & 0.57 & 4.35 & Very High \\
\hline Responsiveness & 0.56 & 4.45 & Very High \\
\hline Assurance & 0.59 & 4.48 & Very High \\
\hline Empathy & 0.56 & 4.43 & Very High \\
\hline Overall & 0.51 & 4.41 & Very High \\
\hline
\end{tabular}

In terms of tangibles as shown in table 1.1, employees being well dressed was the item with the highest mean of 4.50 and a descriptive level of Very High. This was followed by having up-to-date equipment, physical facilities being visually appealing, and visually appealing materials being associated with the service with a mean of 4.27 respectively, all with descriptive levels of Very High.
Table 1.1: Level of Service Quality of an Educational Institution Office Employees in terms of Tangibles

\begin{tabular}{|c|c|c|c|}
\hline Item & SD & Mean & $\begin{array}{c}\text { Descriptive } \\
\text { Level }\end{array}$ \\
\hline Have up-to-date equipment. & 0.70 & 4.27 & Very High \\
\hline $\begin{array}{c}\text { Physical facilities are } \\
\text { visually appealing. }\end{array}$ & 0.68 & 4.27 & Very High \\
\hline $\begin{array}{c}\text { Employees are well dressed } \\
\text { and neat in appearance. }\end{array}$ & 0.68 & 4.50 & Very High \\
\hline $\begin{array}{c}\text { Visually appealing materials } \\
\text { are associated with the } \\
\text { service. }\end{array}$ & 0.71 & 4.27 & Very High \\
\hline Overall & 0.61 & 4.33 & Very High \\
\hline
\end{tabular}

The study also revealed in Table 1.2 the level of service quality of an Educational Institution Office employees in terms of reliability. The item showing sincere interest in solving clients' problem got the highest mean of 4.43 with a descriptive level of Very High; this was followed by providing services at the time promised with a mean of 4.40 and performing the service right the first time with a mean of 4.35 , both with descriptive levels of Very High; and lastly, maintaining error-free records got the lowest mean of 4.21 with a descriptive level of Very High.

Table 1.2: Level of Service Quality of an Educational Institution Office Employees in terms of Reliability

\begin{tabular}{|c|c|c|c|}
\hline Item & SD & Mean & $\begin{array}{c}\text { Descriptive } \\
\text { Level }\end{array}$ \\
\hline $\begin{array}{c}\text { Show sincere interest in } \\
\text { solving clients' problem. }\end{array}$ & 0.62 & 4.43 & Very High \\
\hline $\begin{array}{c}\text { Performs the service right } \\
\text { the first time. }\end{array}$ & 0.65 & 4.35 & Very High \\
\hline $\begin{array}{c}\text { Provides services at the } \\
\text { time promised. }\end{array}$ & 0.65 & 4.40 & Very High \\
\hline $\begin{array}{c}\text { Maintains error-free } \\
\text { records. }\end{array}$ & 0.70 & 4.21 & Very High \\
\hline Overall & 0.57 & 4.35 & Very High \\
\hline
\end{tabular}

In terms of responsiveness as shown in Table 1.3, the item with the highest mean was always willing to help clients, with 4.52 and a descriptive level of Very High. This was followed by ready to respond to clients' request with a mean of 4.46 and a descriptive level of Very High. Offering prompt services to clients and informing clients when services will be performed got the lowest mean of 4.44 and 4.38 respectively, both with descriptive levels of Very High.

Table 1.3: Level of Service Quality of an Educational Institution Office Employees in terms of Responsiveness

\begin{tabular}{|c|c|c|c|}
\hline Item & SD & Mean & $\begin{array}{c}\text { Descriptive } \\
\text { Level }\end{array}$ \\
\hline $\begin{array}{c}\text { Inform customers when } \\
\text { services will be performed. }\end{array}$ & 0.66 & 4.38 & Very High \\
\hline $\begin{array}{c}\text { Offers prompt services to } \\
\text { clients. }\end{array}$ & 0.69 & 4.44 & Very High \\
\hline $\begin{array}{c}\text { Always willing to help } \\
\text { clients. }\end{array}$ & 0.61 & 4.52 & Very High \\
\hline $\begin{array}{c}\text { Readily respond to clients' } \\
\text { request. }\end{array}$ & 0.63 & 4.46 & Very High \\
\hline Overall & 0.56 & 4.45 & Very High \\
\hline
\end{tabular}


In terms of assurance as shown in Table 1.4, it was revealed that the items with the highest mean were making sure that clients feel safe in their transactions and are courteous at all times, both with 4.50 respectively and a descriptive level of Very High; followed by having the knowledge to answer client's questions and being able to in still confidence in clients with a mean of 4.49 and 4.43 respectively, both with descriptive level of Very High.

Table 1.4: Level of Service Quality of an Educational Institution Office Employees in terms of Assurance

\begin{tabular}{|c|c|c|c|}
\hline Item & SD & Mean & $\begin{array}{c}\text { Descriptive } \\
\text { Level }\end{array}$ \\
\hline $\begin{array}{c}\text { Are able to in still } \\
\text { confidence in clients. }\end{array}$ & 0.64 & 4.43 & Very High \\
\hline $\begin{array}{c}\text { Make sure that clients feel } \\
\text { safe in their transactions. }\end{array}$ & 0.61 & 4.50 & Very High \\
\hline Are courteous at all times. & 0.68 & 4.50 & Very High \\
\hline $\begin{array}{c}\text { Have the knowledge to } \\
\text { answer clients' questions. }\end{array}$ & 0.67 & 4.49 & Very High \\
\hline Overall & 0.59 & 4.48 & Very High \\
\hline
\end{tabular}

In terms of empathy as shown in Table 1.5, it was revealed that all the items got the same descriptive level of Very High. Employees understanding clients' needs got the highest mean of 4.49, and was followed by employees having clients best interest at heart and employees giving personal attention to all, both with means of 4.42 respectively. Lastly, having convenient operating hours got the lowest mean of 4.39 .

Table 1.5: Level of Service Quality of an Educational Institution Office Employees in terms of Empathy

\begin{tabular}{|c|c|c|c|}
\hline Item & SD & Mean & $\begin{array}{c}\text { Descriptive } \\
\text { Level }\end{array}$ \\
\hline $\begin{array}{c}\text { Have convenient operating } \\
\text { hours to all. }\end{array}$ & 0.60 & 4.39 & Very High \\
\hline
\end{tabular}

\begin{tabular}{|c|c|c|c|}
\hline $\begin{array}{c}\text { Employees given personal } \\
\text { attention to all. }\end{array}$ & 0.64 & 4.42 & Very High \\
\hline $\begin{array}{c}\text { Employees have clients' } \\
\text { best interest at heart. }\end{array}$ & 0.66 & 4.42 & Very High \\
\hline $\begin{array}{c}\text { Employees understanding } \\
\text { clients' needs. }\end{array}$ & 0.60 & 4.49 & Very High \\
\hline Overall & 0.56 & 4.43 & Very High \\
\hline
\end{tabular}

Significant Difference of the Level of Service Quality of an Educational Institution Office Employees when Analyzed by Office Division

The significant difference of the level of service quality when analyzed by Office Division was presented in Table 2. It was revealed that the overall $F$-value of 0.683 with a p-value of 0.506 which is greater that 0.05 level of significance. This means that the null hypothesis of no significant difference in the service quality of office employees when analyzed by Office Divisions is rejected. It was shown that in terms of tangibles the F-value of 3.538 with a p-value of 0.031 which is less than 0.05 level of significance, thus there is a significant difference on the level of service quality of an educational institution office employees when analyzed by office division in terms of tangibles specifically in SGOD and CID.

The result further revealed that, reliability, responsiveness, assurance, and empathy had no significant difference when analyzed by office divisions, as it posted an F-value of 0.351 with a p-value of 0.704 , an F-value of 0.64 with a p-value 0.938 , an F-value of 1.096 with a p-value of 0.336 , and an Fvalue of 0.487 with a p-value of 0.615 respectively, all are greater than 0.05 level of significance. This means that this factor has no significant difference when analyzed by Office Divisions.

Table 2: Significant Difference of the Level of Service Quality of an Educational Institution Office Employees when Analyzed by Office Division

\begin{tabular}{|c|c|c|c|c|c|c|c|c|c|c|c|}
\hline \multirow{3}{*}{ Factors } & \multicolumn{8}{|c|}{ Division } & \multirow{3}{*}{$\mathrm{F}$} & \multirow{3}{*}{ Sig. } & \multirow{3}{*}{$\begin{array}{c}\text { Means } \\
\text { having } \\
\text { Difference }\end{array}$} \\
\hline & \multicolumn{2}{|c|}{$\begin{array}{c}\text { OSDS } \\
(A)\end{array}$} & \multicolumn{2}{|c|}{$\begin{array}{c}S G O D \\
(B)\end{array}$} & \multicolumn{2}{|c|}{$\begin{array}{l}C I D \\
(C)\end{array}$} & \multicolumn{2}{|c|}{ Total } & & & \\
\hline & Mean & SD & Mean & $\mathrm{SD}$ & Mean & SD & Mean & SD & & & \\
\hline Tangibles & 4.33 & 0.63 & 4.22 & 0.59 & 4.47 & 0.58 & 4.33 & 0.61 & 3.538 & 0.031 & $\mathrm{~B} \& \mathrm{C}$ \\
\hline Reliability & 4.30 & 0.63 & 4.38 & 0.54 & 4.35 & 0.57 & 4.35 & 0.57 & 0.351 & 0.704 & \\
\hline Responsiveness & 4.43 & 0.58 & 4.45 & 0.55 & 4.47 & 0.56 & 4.45 & 0.56 & 0.64 & 0.938 & \\
\hline Assurance & 4.41 & 0.66 & 4.47 & 0.57 & 4.55 & 0.54 & 4.48 & 0.59 & 1.096 & 0.336 & \\
\hline Empathy & 4.40 & 0.63 & 4.40 & 0.54 & 4.48 & 0.53 & 4.43 & 0.56 & 0.487 & 0.615 & \\
\hline Overall & 4.37 & 0.59 & 4.38 & 0.48 & 4.46 & 0.50 & 4.41 & 0.51 & 0.683 & 0.506 & \\
\hline
\end{tabular}


Figure 3

\section{PROPOSED TRAINING DESIGN (A)}

\section{IDENTIFYING INFORMATION}

Activity Title

: Service Quality Enhancement of an

Educational Institution Office Employees in

terms of Tangibles

Activity Type

: Workshop and Training

Activity Area

Program Proponent

Number of Beneficiaries :

Budget Allocation

Source of Funds

Implementing Office

\section{RATIONALE}

In the study conducted by Limama et al. (2021) about the "Service Quality of Pag-IBIG Fund Office Employees: Basis for a Proposed Training Design", based on the conclusion it was recommended to strengthen the level of service quality of an Educational Institution office employees in terms of tangibles.

\section{OBJECTIVES}

At the end of the training program, the participants are expected to have:

1. Equipped with skills and knowledge on quality service delivery especially on tangibles.

2. Broaden knowledge on personal grooming, proper use and placement of office equipment, neat and orderly arranged office materials being associated with the service.

VI. SCHEDULE OF IMPLEMENTATION

\begin{tabular}{|c|c|c|c|c|c|}
\hline Day & Time & Content of Training & Activities & Facilitator & Expected Outcome \\
\hline \multirow[b]{2}{*}{ Day 1} & $\begin{array}{l}\text { 8:00 AM - } \\
12: 00 \mathrm{NN}\end{array}$ & 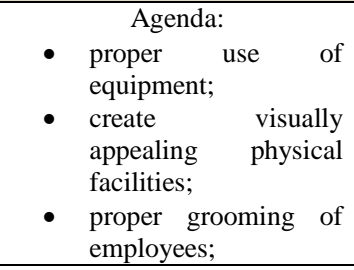 & \multirow{2}{*}{$\begin{array}{l}\text { The following methods } \\
\text { and activities will be } \\
\text { employed: } \\
\text { - } \quad \text { Reading materials } \\
\text { - } \quad \text { Presentation by } \\
\text { instructor/ Subject } \\
\text { Matter Expert } \\
\text { - Hands on activity } \\
\text { - } \quad \text { Group exercise } \\
\text { - } \quad \text { Small group } \\
\text { exercise }\end{array}$} & \multirow{2}{*}{$\begin{array}{c}\text { Human } \\
\text { Resource } \\
\text { Management } \\
\text { Office } \\
\text { Office }\end{array}$} & \multirow{2}{*}{$\begin{array}{l}\text { Improvement of the Service } \\
\text { Quality of an Educational } \\
\text { Institution Office Employees in } \\
\text { terms of tangibles on the } \\
\text { following areas: } \\
\text { - The office will have up-to- } \\
\text { date equipment; } \\
\text { Employees will secure that } \\
\text { physical facilities are } \\
\text { visually appealing to the } \\
\text { clients; } \\
\text { In serving the clients the } \\
\text { employees will be well } \\
\text { dressed and neat in } \\
\text { appearance; will have a } \\
\text { The office wil appealing } \\
\text { visually a a } \\
\text { materials and are } \\
\text { associated with the service. }\end{array}$} \\
\hline & $\begin{array}{c}1: 00 \text { PM to } 5: 00 \\
\text { PM }\end{array}$ & $\begin{array}{l}\text { Agenda: } \\
\text { - } \quad \text { regular monitoring of } \\
\text { materials which are } \\
\text { associate with the } \\
\text { service; } \\
\text { Employees } \\
\text { brainstorming for office } \\
\text { innovations especially } \\
\text { on equipment. }\end{array}$ & & & \\
\hline
\end{tabular}




\section{BUDGETARY REQUIREMENTS}

\begin{tabular}{|c|c|c|c|c|c|}
\hline TRAINING & $\begin{array}{c}\text { EXPENDITURE/ } \\
\text { Employee }\end{array}$ & DURATION & $\begin{array}{c}\text { TOTAL } \\
\text { NO. OF } \\
\text { PARTICIPANTS }\end{array}$ & $\begin{array}{c}\text { AMOUNT } \\
\text { (Expenditure x } \\
\text { Duration x No. of } \\
\text { Participants) }\end{array}$ & GRAND TOTAL \\
\hline $\begin{array}{c}\text { Service Quality } \\
\text { Enhancement of an } \\
\text { Educational Institution } \\
\text { Office Employees in } \\
\text { terms of Tangibles }\end{array}$ & $\begin{array}{c}\text { Snacks (Morning): } 60.00 \\
\text { Meals (Lunch): } 100.00 \\
\text { Snacks (Afternoon): } \\
60.00\end{array}$ & 1 day & $\begin{array}{c}100 \text { Office } \\
\text { employees }\end{array}$ & $32,000.00$ & Php 32,000.00 \\
\hline
\end{tabular}

Figure 4

PROPOSED TRAINING DESIGN (B)

\section{IDENTIFYING INFORMATION}

Activity Title

: Service Quality Enhancement of an

Educational Institution Office Employees in

terms of Reliability

Activity Type

: Workshop and Training

Activity Area

Program Proponent

Number of Beneficiaries :

Budget Allocation

Source of Funds

Implementing Office

\section{RATIONALE}

In the study conducted by Limama et al. (2021) about the "Service Quality of Pag-IBIG Fund Office Employees: Basis for a Proposed Training Design", based on the conclusion it was recommended to strengthen the level of service quality of an Educational Institution office employees in terms of reliability.

\section{OBJECTIVES}

At the end of the training program, the participants are expected to have:

1. Equipped with skills and knowledge on quality service delivery especially on reliability.

2. Developed knowledge on catering clients with sincerity, provide efficient services, performs services with no complaints and errors, and maintains error-free records.

\section{SCHEDULE OF IMPLEMENTATION}

\begin{tabular}{|c|c|c|c|c|c|}
\hline Day & Time & Content of Training & Activities & Facilitator & Expected Outcome \\
\hline \multirow[t]{8}{*}{ Day 1} & $8: 00$ AM - & Agenda: & \multirow{8}{*}{$\begin{array}{l}\text { The following methods } \\
\text { and activities will be } \\
\text { employed: } \\
\text { Reading materials } \\
\text { Presentation by } \\
\text { instructor/Subject Matter } \\
\text { Expert } \\
\text { - Hands on activity } \\
\text { Actual application } \\
\text { of the activity as a group } \\
\text { (acting various front-line }\end{array}$} & \multirow{8}{*}{$\begin{array}{c}\text { Human Resource } \\
\text { Management Office } \\
\text { Office }\end{array}$} & \multirow{8}{*}{$\begin{array}{l}\text { Improvement of the } \\
\text { Service Quality of an } \\
\text { Educational Institution } \\
\text { Office Employees in } \\
\text { terms of reliability on the } \\
\text { following areas: } \\
\text { - The } \\
\text { employees will show } \\
\text { sincere interest in } \\
\text { solving customer's } \\
\text { problem; } \\
\text { - The }\end{array}$} \\
\hline & $12: 00 \mathrm{NN}$ & $\bullet \quad$ Proper & & & \\
\hline & & $\begin{array}{l}\text { clients such as answering } \\
\text { clients' concerns, sincerity in } \\
\text { assisting the clients, etc.; }\end{array}$ & & & \\
\hline & & - Efficiency and & & & \\
\hline & & $\begin{array}{l}\text { consistency of employees in } \\
\text { delivering service to the }\end{array}$ & & & \\
\hline & & clients; & & & \\
\hline & $1: 00 \mathrm{PM}-5: 00$ & Agenda: & & & \\
\hline & PM & Revisit of & & & \\
\hline
\end{tabular}




\begin{tabular}{|c|c|c|c|c|}
\hline & & $\begin{array}{l}\text { People's Freedom of } \\
\text { Information. } \\
\text { - } \quad \text { Revisit of } \\
\text { Freedom of Information } \\
\text { (FOI) Flow Chart. }\end{array}$ & \multirow[t]{2}{*}{$\begin{array}{l}\text { scenarios) } \\
\text { - Small group } \\
\text { exercise. } \\
\text { - } \quad \text { Seminar }\end{array}$} & \multirow{2}{*}{$\begin{array}{l}\text { employees will perform } \\
\text { the service right the first } \\
\text { time; } \\
\text { Employees } \\
\text { will provide services at } \\
\text { the time promised; } \\
\text { Employees } \\
\text { will maintain error-free } \\
\text { records. }\end{array}$} \\
\hline Day 2 & $\begin{array}{c}\text { 8:00 AM - } \\
\text { 12:00 NN } \\
1: 00 \mathrm{PM}-5: 00 \\
\text { PM }\end{array}$ & $\begin{array}{c}\text { Agenda: } \\
\text { - } \quad \text { Seminar } \\
\text { workshop on basic records } \\
\text { and archives management }\end{array}$ & & \\
\hline
\end{tabular}

\section{BUDGETARY REQUIREMENTS}

\begin{tabular}{|c|c|c|c|c|c|}
\hline TRAINING & $\begin{array}{c}\text { EXPENDITURE/ } \\
\text { Employee }\end{array}$ & DURATION & $\begin{array}{c}\text { NO. OF } \\
\text { PARTICIPANTS }\end{array}$ & $\begin{array}{c}\text { AMOUAL } \\
\text { (Expenditure x } \\
\text { Duration x No. of } \\
\text { Participants) }\end{array}$ & GRAND TOTAL \\
\hline $\begin{array}{c}\text { Service Quality } \\
\text { Enhancement of an } \\
\text { Educational Institution } \\
\text { Office Employees in } \\
\text { terms of Reliability }\end{array}$ & $\begin{array}{c}\text { Snacks (Morning): } 60.00 \\
\text { Meals (Lunch): } 100.00 \\
\text { Snacks (Afternoon): } \\
60.00\end{array}$ & 2 days & $\begin{array}{c}100 \text { Office } \\
\text { employees }\end{array}$ & $64,000.00$ & Php 64,000.00 \\
\hline
\end{tabular}

Figure 5

PROPOSED TRAINING DESIGN (C)

\section{IDENTIFYING INFORMATION}

Activity Title

: Service Quality Enhancement of an

Educational Institution Office Employees in

terms of Responsiveness

Activity Type

: Workshop and Training

Activity Area

Program Proponent

Number of Beneficiaries :

Budget Allocation

Source of Funds

Implementing Office

\section{RATIONALE}

In the study conducted by Limama et al. (2021) about the "Service Quality of Pag-IBIG Fund Office Employees: Basis for a Proposed Training Design", based on the conclusion it was recommended to strengthen the level of service quality of an Educational Institution office employees in terms of responsiveness.

\section{OBJECTIVES}

At the end of the training program, the participants are expected to have:

1. Equipped with skills and knowledge on quality service delivery especially on responsiveness.

2. Enhanced abilities on informing clients properly, offer prompt services to customers, willingness to help clients, and readily respond to clients' requests. 
VI. SCHEDULE OF IMPLEMENTATION

\begin{tabular}{|c|c|c|c|c|c|}
\hline Day & Time & Content of Training & Activities & Facilitator & Expected Outcome \\
\hline \multirow[t]{2}{*}{ Day 1} & $\begin{array}{l}\text { 8:00 AM - } \\
12: 00 \mathrm{NN}\end{array}$ & $\begin{array}{l}\text { Agenda: } \\
\text { - Proper } \\
\text { information for the clients } \\
\text { when services will be } \\
\text { performed; } \\
\text { catering clients; }\end{array}$ & \multirow{2}{*}{$\begin{array}{l}\text { The following methods } \\
\text { and activities will be } \\
\text { employed: } \\
\text { - Reading materials } \\
\text { - Presentation by } \\
\text { instructor/Subject Matter } \\
\text { Expert } \\
\text { - Hands on activity } \\
\text { - Actual application } \\
\text { of the activity as a group } \\
\text { (acting various front-line } \\
\text { scenarios) } \\
\text { - Small group } \\
\text { exercise. }\end{array}$} & \multirow[t]{3}{*}{$\begin{array}{c}\text { Human Resource } \\
\text { Management Office } \\
\text { Office }\end{array}$} & \multirow{3}{*}{$\begin{array}{l}\text { Improvement of the } \\
\text { Service Quality of an } \\
\text { Educational Institution } \\
\text { Office Employees in } \\
\text { terms of responsiveness } \\
\text { on the following areas: } \\
\text { - } \quad \text { Employees } \\
\text { will inform clients when } \\
\text { services will be } \\
\text { performed; } \\
\text { - } \quad \text { Employees } \\
\text { will offer prompt } \\
\text { services to customers; } \\
\text { - } \quad \text { Employees } \\
\text { will be always willing to } \\
\text { help clients; } \\
\text { - } \quad \text { Employees } \\
\text { will respond readily to } \\
\text { clients' request. }\end{array}$} \\
\hline & $\begin{array}{c}\text { 1:00 PM - 5:00 } \\
\text { PM }\end{array}$ & $\begin{array}{l}\text { Agenda: } \\
\text { - } \quad \text { Eagerness to help } \\
\text { clients for public assistance; } \\
\text { c } \quad \text { Fast response in } \\
\text { catering clients' request. }\end{array}$ & & & \\
\hline Day 2 & $\begin{array}{c}\text { 8:00 AM - } \\
\text { 12:00 NN } \\
1: 00 \mathrm{PM}-5: 00 \\
\text { PM }\end{array}$ & $\begin{array}{l}\text { Agenda: } \\
\text { Moral recovery } \\
\text { program }\end{array}$ & Whole day Seminar & & \\
\hline
\end{tabular}

\section{BUDGETARY REQUIREMENTS}

\begin{tabular}{|c|c|c|c|c|c|}
\hline TRAINING & $\begin{array}{l}\text { EXPENDITURE/ } \\
\text { Employee }\end{array}$ & DURATION & $\begin{array}{c}\text { NO. OF } \\
\text { PARTICIPANTS }\end{array}$ & $\begin{array}{c}\text { TOTAL } \\
\text { AMOUNT } \\
\text { (Expenditure } x \\
\text { Duration x No. of } \\
\text { Participants) }\end{array}$ & GRAND TOTAL \\
\hline $\begin{array}{c}\text { Service Quality } \\
\text { Enhancement of an } \\
\text { Educational Institution } \\
\text { Office Employees in } \\
\text { terms of Responsiveness }\end{array}$ & $\begin{array}{c}\text { Snacks (Morning): } 60.00 \\
\text { Meals (Lunch): } 100.00 \\
\text { Snacks (Afternoon): } \\
60.00 \\
\text { Training Materials: } 100\end{array}$ & 2 days & $\begin{array}{l}100 \text { Office } \\
\text { employees }\end{array}$ & $64,000.00$ & Php 64,000.00 \\
\hline
\end{tabular}

Figure 6

\section{PROPOSED TRAINING DESIGN (D)}

\section{IDENTIFYING INFORMATION}

Activity Title

: Service Quality Enhancement of an

Educational Institution Office Employees in

terms of Assurance

Activity Type

: Workshop and Training

Activity Area

Program Proponent

Number of Beneficiaries :

Budget Allocation

Source of Funds

Implementing Office 


\section{RATIONALE}

In the study conducted by Limama et al. (2021) about the "Service Quality of Pag-IBIG Fund Office Employees: Basis for a Proposed Training Design", based on the conclusion it was recommended to strengthen the level of service quality of an Educational Institution office employees in terms of assurance.

\section{OBJECTIVES}

At the end of the training program, the participants are expected to have:

1. Equipped with skills and knowledge on quality service delivery especially on assurance.

2. Improved the capabilities on in stilling confidence to the clients, making clients comfortable and safe with their transactions, employees are always courteous, and knowledgeable in answering queries of clients.

VI. SCHEDULE OF IMPLEMENTATION

\begin{tabular}{|c|c|c|c|c|c|}
\hline Day & Time & Content of Training & Activities & Facilitator & Expected Outcome \\
\hline \multirow[b]{2}{*}{ Day 1} & $\begin{array}{l}\text { 8:00 AM - } \\
12: 00 \mathrm{NN}\end{array}$ & $\begin{array}{c}\text { Agenda: } \\
\text { - Guarantee and clients } \\
\text { being comfortable with } \\
\text { the employees in office } \\
\text { transactions; } \\
\text { - Transparency of the } \\
\text { services. }\end{array}$ & \multirow{2}{*}{$\begin{array}{l}\text { The following methods } \\
\text { and activities will be } \\
\text { employed: } \\
\text { - Reading materials } \\
\text { - Presentation by } \\
\text { instructor/ Subject } \\
\text { Matter Expert } \\
\text { - Hands on activity } \\
\text { - Actual application of } \\
\text { the activity as a group } \\
\text { (acting various front- } \\
\text { line scenarios) } \\
\text { - Small group exercise. } \\
\text { - Seminar }\end{array}$} & \multirow{2}{*}{$\begin{array}{c}\text { Human Resource } \\
\text { Management Office } \\
\text { Office }\end{array}$} & \multirow{2}{*}{$\begin{array}{l}\text { Improvement of the } \\
\text { Service Quality of an } \\
\text { Educational Institution } \\
\text { Office Employees in } \\
\text { terms of assurance on the } \\
\text { following areas: } \\
\text { - Employees will be } \\
\text { able to instill } \\
\text { confidence in clients; } \\
\text { - Employees will make } \\
\text { sure that clients feel } \\
\text { safe in their } \\
\text { transactions; } \\
\text { - Employees are } \\
\text { courteous at all } \\
\text { times; employees } \\
\text { will be knowledgea- } \\
\text { ble in answering } \\
\text { clients' questions. }\end{array}$} \\
\hline & $\begin{array}{c}1: 00 \mathrm{PM}-5: 00 \\
\mathrm{PM}\end{array}$ & $\begin{array}{l}\text { Agenda: } \\
\text { - } \quad \text { Revisit on the office } \\
\text { manual of operations; } \\
\text { Proper ethics in front- } \\
\text { line services. }\end{array}$ & & & \\
\hline
\end{tabular}

\section{BUDGETARY REQUIREMENTS}

\begin{tabular}{|c|c|c|c|c|c|}
\hline TRAINING & $\begin{array}{c}\text { EXPENDITURE/ } \\
\text { Employee }\end{array}$ & DURATION & $\begin{array}{c}\text { TOTAL OF } \\
\text { PARTICIPANTS }\end{array}$ & $\begin{array}{c}\text { AMOUNT } \\
\text { (Expenditure x } \\
\text { Duration x No. of } \\
\text { Participants) }\end{array}$ & GRAND TOTAL \\
\hline $\begin{array}{c}\text { Service Quality } \\
\text { Enhancement of an } \\
\text { Educational Institution } \\
\begin{array}{c}\text { Office Employees in } \\
\text { terms of Assurance }\end{array}\end{array}$ & $\begin{array}{c}\text { Snacks (Morning): } 60.00 \\
\text { Meals (Lunch): } 100.00 \\
\text { Snacks (Afternoon): } \\
60.00\end{array}$ & 1 day & $\begin{array}{c}100 \text { Office } \\
\text { employees }\end{array}$ & $32,000.00$ & Php 32,000.00 \\
\hline
\end{tabular}

Figure 7

PROPOSED TRAINING DESIGN (E)

\section{IDENTIFYING INFORMATION}

Activity Title

: Service Quality Enhancement of an

Educational Institution Office Employees in 
terms of Empathy

$\begin{array}{lll}\text { Activity Type } & : \text { Workshop and Training } \\ \text { Activity Area } & : \\ \text { Program Proponent } & : \\ \text { Number of Beneficiaries }: & \\ \text { Budget Allocation } & : \\ \text { Source of Funds } & : \\ \text { Implementing Office } & :\end{array}$

\section{RATIONALE}

In the study conducted by Limama et al. (2021) about the "Service Quality of Pag-IBIG Fund Office Employees: Basis for a Proposed Training Design", based on the conclusion it was recommended to strengthen the level of service quality of an Educational Institution office employees in terms of empathy.

\section{OBJECTIVES}

At the end of the training program, the participants are expected to have:

1. Equipped with skills and knowledge on quality service delivery especially on empathy.

2. Fortified with attitude in understanding the differences of the clients respect and comprehend clients in various unkind situations.

VI. SCHEDULE OF IMPLEMENTATION

\begin{tabular}{|c|c|c|c|c|c|}
\hline Day & Time & Content of Training & Activities & Facilitator & Expected Outcome \\
\hline \multirow[t]{2}{*}{ Day 1} & $\begin{array}{l}\text { 8:00 AM - } \\
12: 00 \mathrm{NN}\end{array}$ & $\begin{array}{l}\text { Agenda: } \\
\text { Convenient office } \\
\text { for the clients; } \\
\text { Accommodating } \\
\text { employees. }\end{array}$ & \multirow{2}{*}{$\begin{array}{l}\text { The following methods } \\
\text { and activities will be } \\
\text { employed: } \\
\text { Reading materials } \\
\text { - } \quad \text { Presentation by } \\
\text { instructor/ Subject } \\
\text { Matter Expert } \\
\text { - Hands on activity } \\
\text { - Actual application } \\
\text { of the activity as a group } \\
\text { (acting various front-line } \\
\text { scenarios) } \\
\text { Small group } \\
\text { exercise. }\end{array}$} & \multirow[t]{2}{*}{$\begin{array}{l}\text { Human Resource } \\
\text { Management } \\
\text { Office } \\
\text { Office }\end{array}$} & \multirow{2}{*}{$\begin{array}{l}\text { Improvement of the Service } \\
\text { Quality of an Educational } \\
\text { Institution Office Employees } \\
\text { in terms of empathy on the } \\
\text { following areas: } \\
\text { - Office have convenient } \\
\text { operating hours to all; } \\
\text { - Employees give personal } \\
\text { attention to all; } \\
\text { - Employees have clients } \\
\text { best interest at heart; } \\
\text { - Employees } \\
\text { understanding clients' } \\
\text { needs. }\end{array}$} \\
\hline & $\begin{array}{c}1: 00 \mathrm{PM}-5: 00 \\
\text { PM }\end{array}$ & $\begin{array}{c}\text { Agenda: } \\
\text { - } \quad \text { Customer is } \\
\text { always right; } \\
\text { employees towards clients. }\end{array}$ & & & \\
\hline
\end{tabular}

\section{BUDGETARY REQUIREMENTS}

\begin{tabular}{|c|c|c|c|c|c|}
\hline TRAINING & $\begin{array}{l}\text { EXPENDITURE/ } \\
\text { Employee }\end{array}$ & DURATION & $\begin{array}{c}\text { NO. OF } \\
\text { PARTICIPANTS }\end{array}$ & $\begin{array}{c}\text { TOTAL } \\
\text { AMOUNT } \\
\text { (Expenditure } \mathrm{x} \\
\text { Duration x No. of } \\
\text { Participants) } \\
\end{array}$ & GRAND TOTAL \\
\hline $\begin{array}{c}\text { Service Quality } \\
\text { Enhancement of an } \\
\text { Educational Institution } \\
\text { Office Employees in } \\
\text { terms of Empathy }\end{array}$ & $\begin{array}{c}\text { Snacks (Morning): } 60.00 \\
\text { Meals (Lunch): } 100.00 \\
\text { Snacks (Afternoon): } \\
60.00 \\
\text { Training Materials: } 100\end{array}$ & 1 day & $\begin{array}{l}100 \text { Office } \\
\text { employees }\end{array}$ & $32,000.00$ & Php 32,000.00 \\
\hline
\end{tabular}

\section{DISCUSSION}

This chapter presents the discussion of the data on the service quality of an educational institution office employees. The discussion in this chapter starts with the level of service quality of an educational institution office employees in terms of tangibles, reliability, responsiveness, assurance, and empathy. Then, the significant difference of service quality when analyzed by office division: Office of the Schools 
Division Superintendent (OSDS), Schools Governance and Operations Division (SGOD), and Curriculum and Implementation Division (CID) are discussed.

\section{Service Quality of an Educational Institution Office Employees}

In Table 1, the study revealed that the overall level of Service Quality of an Educational Institution office employees as observed by the clients is very high, which means that the service quality of an Educational Institution Office Employees is always felt/manifested. The results further show that tangibles, reliability, responsiveness, assurance, and empathy are the quality of service with very high descriptive levels which means that the service quality stated is always felt/manifested. The result of the study is opposite to the study of Wisniewski (2001) where the analysis of gap scores revealed that reliability and responsiveness had negative gaps.

As presented in Table 1, the result showed that the indicator tangibles got the lowest mean. Specifically, in Table 1.1 employees being well dressed and neat in appearance item got the highest mean with a descriptive level of very high. Then, items having up-to-date equipment, physical facilities being visually appealing, and visually appealing materials being associated with the service have the same means with a descriptive level of very high which means that the service quality of an educational institution is always felt/manifested by the office employees. In contrary, on the researches of Chase (1987) and Safizadeh et al. (2003), they discussed that discrepancy and uncertainties in the service delivery system requires design of facilities in the production system. Conversely, Nor et al (2010) states public complaints of poor physical facilities are not adequate to affect the image and the quality level of service in the public sector.

The result also showed that in Table 1, the second indicator that got the lowest mean was reliability. It was revealed in Table 1.2 that the observation of clients with the items show sincere interest in solving clients; problem, performs the service right the first time, provides services at the time promised, and maintains error-free records was very high level of service quality. This means that the Service Quality of Pag-IBIG Fund Office Employees is always felt/manifested. The result is parallel to the study of Lassar (2005); Manolis (2007) and Winsor (2007) that profound focus on understanding the determinants and antecedents of the satisfaction of customer had an extremely high value for organizational services in competitive environments.

Next is the indicator responsiveness got the second highest mean with very high descriptive level. As per the results this indicator is always manifested by the clients. In Table 1.3, the results further revealed that clients always felt that the office employees inform clients when services will be performed, offers prompt services to clients, always willing to help clients, and readily respond to clients' request. The finding is parallel to the study of Solomon et al. (1985) and Matzler et al. (2004) that front-line employees are full of knowledge about the strengths and weaknesses of the services in organizations through their direct interactions with the clients which is very important form of feedback that can be utilized by the organizations in making decisions to better serve clients.

Then, assurance got the highest mean with a descriptive level of very high where in Table 1.4, it shows that the clients always observed that office employees are able to instill confidence in clients, make sure that clients feel safe in their transactions, are courteous at all time, and have the knowledge to answer clients' questions. The result is parallel to the study of Zeithaml and Bitner (1996) that front-line employees' good performance with their functions will be advantageous to the organizations while their poor performance will result to detriment of the organization. It was supported by Bettencourt and Gwinner (1996) that frontline employees can modify not only the services of the organization, but also their strategies on delivering those services.

Lastly, the indicator empathy has a mean next to responsiveness with a descriptive level of very high. As showed in Table 1.3 the clients responded that this indicator is always observed on the service quality of an Educational Institution Office Employees. Further, they always observed the items have convenient operating hours to all, employees given personal attention to all, employees have clients' best interest at hear, and employees understanding clients' need. The finding is parallel to the study of Zeithaml et al. (2006) where they emphasized that the delivered services by the public in real time, service performances gap's closing were profoundly dependent on the strategies of human resource. This was supported by the study of Wetherall et al. (1984) that the clients believe to have positive perspectives on technology-based quality of services because they considered that technology is more efficient and can deliver faster services than employee. Thus, the employees may depend on the facility alone and will not respond well to the client's request.

\section{Significant Difference of the Level of Service Quality of an Educational Institution when Analyzed by Office Division}

This study is anchored on the proposition of Gowan et al. (2001), who stated that service provision is more complex in the public sector because it is not simply a matter of meeting expressed needs, but of finding out unexpressed needs, setting priorities, allocating resources and publicly justifying and accounting for what has been done. Besides, the results of the study show that there is significant difference of the level of service quality when analyzed by Office Division. It was revealed that in the indicator tangibles the F-value of 0.683 with a p-value of 0.506 which is less than 0.05 level of significance. This means that the null hypothesis of no significant difference in the service quality of office employees when analyzed by office divisions is rejected. There is significant difference in the Schools Governance and Operations Division (SGOD) and Curriculum Implementation Division (CID) specifically in the indicator tangibles. 
This study was also anchored on Nor et al (2010) that public sector organizations, which provide customer service is one of the important factors that gives significant contribution to build good reputation and credibility in the community. Public complaints of long queues, poor service and poor physical facilities are not adequate to affect the image and the quality level of service in the public sector.

\section{CONCLUSION}

Based on the results of the study the following conclusions were drawn:

The level of service quality of an Educational Institution office employees in all the indicators tangibles, reliability, responsiveness, assurance, and empathy are very high which means that the service quality of an Educational Institution Office Employees was always felt/manifested.

Furthermore, the result of the study also concluded that there is significant difference of the level of service quality when analyzed by Office Divisions which resulted to the rejection of the null hypothesis; that the level of Service Quality of an Educational Institution Office Employees is very high which means it is always felt/manifested by the clients. This means that tangibles, reliability, responsiveness, assurance, and empathy when examined by division, the level of Service Quality of an Educational Institution Office Employees is very high.

\section{RECOMMENDATION}

Based on the conclusions of the study, the following are highly recommended:

It is suggested to strengthen the level of service quality of an Educational Institution office employees in terms of tangibles, reliability, responsiveness, assurance, and empathy.

The overall results on the level of service quality of an educational institution office employees revealed the overall mean was 4.41 with a descriptive level of very high which means that the clients of an educational institution office always felt/manifested the quality of services. It is therefore recommended that the further study be conducted to find out more on the factors that affect the service quality not only on a certain organization, but also on a wider range. It is therefore recommended that the further study be conducted to find out what attributes more significantly influence the service quality of an educational institution office employees when analyzed by office division.

\section{REFERENCES}

[1] Agus, A., Barker, S. \& Kandampully, J. (2007). An exploratory study of service quality in the Malaysian public service sector. International Journal of Quality \& Reliability Management, 24(2), 177-190.

[2] Ahmed, I. \& Islam, T. (2011). Decoding the relationship between employee's jobs related behaviors: A study of telecom sector of Pakistan. International Journal of Business and Social Science, 2(8).
[3] Akhtar, Z. \& Udham, S. (2010). Job involvement: A theoretical interpretation in different work settings. Retrieved from Indian MBA. com.

[4] Albdour, A. A. \& Altarawneh, I. I. (2014). Employee engagement and organizational commitment: Evidence from Jordan. International Journal of Business, 19(2), 192.

[5] Allen, N. J. \& Meyer, J. P. (1996). Affective, continuance, and normative commitment to the organization: An examination of construct validity. Journal of vocational behavior, 49(3), 252-276.

[6] Hollon, D., Miller, I. J., \& Robinson, E. (2002). Criteria for evaluating treatment guidelines. American Psychologist, 57(12), 1052-1059.

[7] Ananth, A., Ramesh, R. \& Prabaharan, B. (2010). Service quality gap analysis in private sector bank-a customer perspective. Retrieved from https://mpra.ub.unimuenchen.de/29505/1/Paper_24.pdf

[8] Anderson, E. A. (1995). Measuring service quality at a university health clinic. International Journal of Health Care Quality Assurance, 8(2), 32-37.

[9] Appleton, K., House, A. \& Dowell, A. (1998). A survey of job satisfaction, sources of stress and psychological symptoms among general practitioners in Leeds. Br J Gen Pract, 48(428), 10591063.

[10] Avila, J. (2014). Report on the administration of the report card survey in the Cities of Batangas, Iloilo and Cagayan de Oro. Retrieved

from https://www.google.com.ph/\#q=Report+on+the+Administration+o $\mathrm{f}+$ the+Report+Card+Survey+in+the+Cities+of+Batangas $\% 2 \mathrm{C}+$ Ilo ilo+and+Cagayan+de+Oro

[11] Azar, S. \& Khan, S. (2012). Service Quality of Higher Education in Pakistan. Asian Journal of University Education, 8(1), 107-122.

[12] Babakus, E. \& Boller, G. W. (1992). An empirical assessment of the SERVQUAL scale. Journal of Business research, 24(3), 253268.

[13] Babakus, E. \& Mangold, W. G. (1992). Adapting the SERVQUAL scale to hospital services: an empirical investigation. Health services research, 26(6), 767.

[14] Bakar, C., Seval Akgün, H. \& Al Assaf, A. F. (2008). The role of expectations in patient assessments of hospital care: an example from a university hospital network, Turkey. International Journal of Health Care Quality Assurance, 21(4), 343-355.

[15] Ballesteros, M. M. \& Egana, J. V. (2013). Efficiency and effectiveness review of the National Housing Authority (NHA) resettlement program (No. 2013-28). Retrieved from https://www.econstor.eu/handle/10419/126958

[16] Barney, J. (1991). Firm resources and sustained competitive advantage. Journal of management, 17(1), 99-120.

[17] Brislin, R. W. \& Yoshida, T. (Eds.). (1993). Improving intercultural interactions: Modules for cross-cultural training programs. Thousand Oaks, CA: Sage Publications Inc.

[18] Bashir, S. \& Ramay, M. I. (2008). Determinants of organizational commitment: a study of information technology professionals in Pakistan. Journal of Behavioral and Applied Management, 9(2), 226.

[19] Berry, L. L., Parasuraman, A. \& Zeithaml, V. A. (1994). Improving service quality in America: lessons learned. The Academy of Management Executive, 8(2), 32-45.

[20] Beatson, A., Lings, I. \& Gudergan, S. (2008). Employee behaviour and relationship quality: impact on customers. The Service Industries Journal, 28(2), 211-223.

[21] Bettencourt, L. A. \& Gwinner, K. (1996). Customization of the service experience: the role of the frontline employee. International journal of service industry management, 7(2), 3-20.

[22] Bitner, M. J., Booms, B. H. \& Mohr, L. A. (1994). Critical service encounters: The employee's viewpoint. The journal of marketing, 95-106.

[23] Bowen, D. E. (1986). Managing customers as human resources in service organizations. Human resource management, 25(3), 371383.

[24] Bowie, V. (1996). Coping with violence: A guide for the human services. London: Whiting and Burch Limited. 
[25] Brown, T. J., Churchill Jr, G. A. \& Peter, J. P. (1993). Research note: improving the measurement of service quality. Journal of retailing, 69(1), 127.

[26] Brysland, A. \& Curry, A. (2001). Service improvements in public services using SERVQUAL. Managing Service Quality: An International Journal, 11(6), 389-401.

[27] Cable, D. M. \& DeRue, D. S. (2002). The convergent and discriminant validity of subjective fit perceptions. Journal of applied psychology, 87(5), 875 .

[28] Carman, J. M. (1990). Consumer perceptions of service quality: an assessment of the SERVQUAL dimensions. Journal of retailing, 66(1), 33 .

[29] Caron, D. J. \& Giauque, D. (2006). Civil servant identity at the crossroads: new challenges for public administrations. International Journal of Public Sector Management, 19(6), 543-555.

[30] Çeliköz, N. (2009). Basic factors that affect general academic motivation levels of candidate preschool teachers. Procedia-Social and Behavioral Sciences, 1(1), 1357-1365.

[31] Challenger, J. A. (2000). 24 trends reshaping the workplace. The Futurist, 34(5), 35.

[32] Check, J. \& Schutt, R. K. (2011). Research methods in education. Boston, USA: Sage Publications Inc.

[33] Chen, J. \& Wang, L. (2007). Locus of control and the three components of commitment to change. Personality and individual differences, 42(3), 503-512.

[34] Chow-Chua, C. \& Komaran, R. (2002). Managing service quality by combining voice of the service provider and voice of their customers. Managing Service Quality: An International Journal, 12(2), 77-86.

[35] Chrisman, N. J. (2007). Extending cultural competence through systems change: Academic, hospital, and community partnerships. Journal of Transcultural Nursing, 18(1), 68-76.

[36] Chughtai, A. A. (2008). Impact of job involvement on in-role job performance and organizational citizenship behaviour. Journal of Behavioral and Applied Management, 9(2), 169.

[37] Costello, A. B. \& Osborne, J. W. (2005). Best practices in exploratory factor analysis: Four recommendations for getting the most from your analysis. Practical assessment, research \& evaluation, 10(7), 1-9.

[38] Creswell, J. W. \& Garrett, A. L. (2008). The movement of mixed methods research and the role of educators. South African journal of education, 28(3), 321-333.

[39] Cook, C. T., Kosoko-Lasaki, O. \& O'Brien, R. (2005). Satisfaction with and perceived cultural competency of healthcare providers: the minority experience. Journal of the National Medical Association, 97(8), 1078

[40] Cronin Jr, J. J. \& Taylor, S. A. (1992). Measuring service quality: a reexamination and extension. The journal of marketing, 55-68.

[41] Czepiel, J. A. (1990). Service encounters and service relationships: implications for research. Journal of business research, 20(1), 1321.

[42] Dabholkar, P. A. (1994). Technology-based service delivery: a classification scheme for developing marketing strategies. Advances in services marketing and management, 3(1), 241-271.

[43] De Venecia, J. A. (2015, July 06). Members' concerns are our priority - Pag-Ibig. Retrieve from http://opinion.inquirer.net/86438/members-concerns-are-ourpriority-pag-ibig\#ixzz53IhjurTy on January 05, 2018.

[44] DeLeon, P. (1999). The stages approach to the policy process: What has it done? Where is it going. Theories of the policy process, 1(19), 19-32.

[45] Dedeke, A. (2003). Service quality: a fulfilment-oriented and interactions-centred approach. Managing Service Quality: An International Journal, 13(4), 276-289.

[46] Deolalikar, A. B., \& Jha, S. (2013). Empowerment and public service delivery in developing Asia and the Pacific (36). Manila: Asian Development Bank. Retrieved from http://mts.asu.lt/mtsrbid/article/view/966
[47] Donnelly, M., Wisniewski, M., Dalrymple, J. F., \& Curry, A. C. (1995). Measuring service quality in local government: the SERVQUAL approach. International Journal of Public Sector Management, 8(7), 15-20.

[48] Donnelly, M. (1999). Making the difference: quality strategy in the public sector. Managing Service Quality: An International Journal, 9(1), 47-52.

[49] Donnelly, M., Kerr, N. J., Rimmer, R. \& Shiu, E. M. (2006). Assessing the quality of police services using SERVQUAL. Policing: An International Journal of Police Strategies \& Management, 29(1), 92-105.

[50] Ekmekçi, A. K. (2011). A study on involvement and commitment of employees in Turkey. Journal of Public Administration and Policy Research, 3(3), 68.

[51] Fabrigar, L. R., Wegener, D. T., MacCallum, R. C. \& Strahan, E. J. (1999). Evaluating the use of exploratory factor analysis in psychological research. Psychological methods, 4(3), 272.

[52] Field, A. (2000). Discovering statistics using SPSS for windows, edited. Wright D. London. Thousand Oaks. New.

[53] Fountain, J. E. \& Osorio-Urzua, C. (2001). The economic impact of the Internet on the government sector. The Economic Payoff from the Internet Revolution, 2(4), 354.

[54] Freund, A. \& Carmeli, A. (2003). An empirical assessment: reconstructed model for five universal forms of work commitment. Journal of Managerial Psychology, 18(7), 708-725.

[55] Galloway, L. (1998). Quality perceptions of internal and external customers: A case study in educational administration. The TQM Magazine, 10(1), 20-26.

[56] Galais, N. \& Moser, K. (2009). Organizational commitment and the well-being of temporary agency workers: A longitudinal study. Human Relations, 62(4), 589-620.

[57] Garcia-Zamor, J. C. (2015). Quality of governance and ethical public service delivery (PSD) in developing countries. Journal of management and strategy, 6(3), 28.

[58] Gay, L. R., Mills, G. E. \& Airasian, P. W. (1996). Educational research: Competencies for analysis and application.

[59] Gilbert, M. J. (Ed.). (2003). Principles and recommended standards for cultural competence education of health care professionals. $\quad$ Retrieved from https://www.mghihp.edu/sites/default/files/aboutus/diversity/principles_standards_cultural_competence.pdf

[60] Gore, A. (1993). From red tape to results: creating a government that works better \& costs less: executive summary: the national performance review. US: Diane Publishing.

[61] Govender, S. \& Parumasur, S. B. (2010). The relationship between employee motivation and job involvement. South African Journal of Economic and Management Sciences, 13(3), 237-253.

[62] Gowan, M., Seymour, J., Ibarreche, S. \& Lackey, C. (2001). Service quality in a public agency: same expectations but different perceptions by employees, managers, and customers. Journal of quality management, 6(2), 275-291.

[63] Gronroos, C. (1988). Service quality: The six criteria of good perceived service. Review of business, 9(3), 10.

[64] Guerrier, Y. \& Deery, M. (1998). Research in hospitality human resource management and organizational behaviour. International Journal of Hospitality Management, 17(2), 145-160.

[65] Greene, M. (1995). Releasing the imagination: Essays on education, the arts, and social change. Jossey-Bass.

[66] Head, B. \& McCoy, E. (Eds.). (1991). Deregulation Or Better Regulation?: Issues for the Public Sector. South Melbourne: Macmillan Education AU.

[67] Hull, J. (2007). Consumer's guide to education research. Center for Public Education. Retrieved from http://www. centerforpubliceducation. org/Main-Menu/Policies/Consumersguide-to-education-research/default. aspx.

[68] Ilhaamie, A. G. A. (2010). Service quality in Malaysian public service: some findings. International Journal of Trade, Economics and Finance, 1(1), 40.

[69] Jalalian, M., Sayadi, V. \& Shabankareh, N. (2014). Investigation and identification of Factors Affecting Reduction of the Motive of Keshavarzi Bank Employees in Tehran Province 
Branches. International Journal of Academic Research in Accounting, Finance and Management Sciences, 4(3), 173-181.

[70] Jalonen, P., Virtanen, M., Vahtera, J., Elovainio, M. \& Kivimaki, M. (2006). Predictors of sustained organizational commitment among nurses with temporary job contracts. Journal of Nursing Administration, 36(5), 268-276.

[71] Johnson, C. (2007). The sorrows of empire: Militarism, secrecy, and the end of the republic. New York: Metropolitan Books.

[72] Joseph, M., McClure, C. \& Joseph, B. (1999). Service quality in the banking sector: the impact of technology on service delivery. International journal of bank marketing, 17(4), 182-193.

[73] Kangis, P. \& Passa, V. (1997). Awareness of service charges and its influence on customer expectations and perceptions of quality in banking. Journal of Services Marketing, 11(2), 105-117.

[74] Khan, K. \& Nemati, A. R. (2011). Impact of job involvement on employee satisfaction: A study based on medical doctors working at Riphah International University Teaching Hospitals in Pakistan. African Journal of Business Management, 5(6), 2241.

[75] Khan, T. I., Jam, F. A., Akbar, A., Khan, M. B. \& Hijazi, S. T. (2011). Job involvement as predictor of employee commitment: Evidence from Pakistan. International Journal of Business and Management, 6(4), 252.

[76] Kiyani, A., Haroon, M., Khattak, M. A., Liaqat, A. S., Bukhari, S. J. A. \& Asad, R. (2011). Impact of career salience on universities teachers' job involvement: A study on public and private universities in Pakistan. African Journal of Business Management, 5(5), 1795.

[77] Kumar, M., Tat Kee, F. \& Taap Manshor, A. (2009). Determining the relative importance of critical factors in delivering service quality of banks: an application of dominance analysis in SERVQUAL model. Managing Service Quality: An International Journal, 19(2), 211-228.

[78] Langford, J. \& Roy, J. (2006). E-government and public-private partnerships in Canada: when failure is no longer an option. International Journal of Electronic Business, 4(2), 118135.

[79] Lassar, W. M., Manolis, C. \& Winsor, R. D. (2000). Service quality perspectives and satisfaction in private banking. Journal of services marketing, 14(3), 244-271.

[80] Locke, E. (1976). The nature and causes of job satisfaction. In M.D Dunnette ( $1^{\text {st }}$ ed), Handbook of industrial and organizational psychology. (pp. 1297-1349). Chicago, IL: Rand Mcnally.

[81] Lewis, B. R. \& Mitchell, V. W. (1990). Defining and measuring the quality of customer service. Marketing intelligence \& planning, 8(6), 11-17.

[82] Luk, S. T. (1997). An examination of the role of marketing culture in service quality. International Journal of Contemporary Hospitality Management, 9(1), 13-20.

[83] Mahal, A., Srivastava, V. \& Sanan, D. (2000). Decentralization and public sector delivery of health and education services: The Indian experience (No. 20). ZEF discussion papers on development policy.

[84] Malik, M. E., Nawab, S., Naeem, B. \& Danish, R. Q. (2010). Job satisfaction and organizational commitment of university teachers in public sector of Pakistan. International journal of business and management, 5(6), 17.

[85] Manasan, R. G. (2007). Decentralization and the financing of regional development. The Dynamics of Regional Development: The Philippines in East Asia. Cheltenham, UK: Edward Elgar Publishing, Inc, 275-315.

[86] Mendoza, M. L. (2011). Legislating Citizen's Charters. Development Academy of the Philippines.

[87] Metters, R. \& Vargas, V. (2000). A typology of de-coupling strategies in mixed services. Journal of Operations Management, 18(6), 663-682.

[88] Mittal, S., Gandhi, S. \& Tripathi, G. (2010). Socio-economic impact of mobile phones on Indian agriculture (p. 53). New Delhi: Indian Council for Research on International Economic Relations.

[89] Moynihan, D. P. \& Pandey, S. K. (2007). Finding workable levers over work motivation: Comparing job satisfaction, job involvement, and organizational commitment. Administration \& Society, 39(7), 803-832.
[90] Matzler, K., Fuchs, M. \& Schubert, A. (2004). Employee satisfaction: does Kano's model apply? Total Quality Management \& Business Excellence, 15(9-10), 1179-1198.

[91] Nor, M. N., Khalid, S. A., Razali, M. F. M. \& Ramli, N. A. (2010). Service quality and customer satisfaction: The public sector perspective. Faculty of Business and Management, Universiti Teknologi MARA, Perlis.

[92] Nunnally, J.C. (1994), Psychometric Methods, New York, N.Y: McGraw-Hill Book Company.

[93] Ooesterom,W., Ratan, N.,Varma, N.,de Montfort, R., Pierre, P. \& Lloyd, C. (2007). The Road Ahead for Public Service Delivery. Retrieved from https://www.pwc.com/gx/en/psrc/pdf/the_road_ahead_for_public_ service_delivery.pdf

[94] Parasuraman, A., Zeithaml, V. A. \& Berry, L. L. (1985). A conceptual model of service quality and its implications for future research. The Journal of Marketing, 63(1), 41-50.

[95] Parasuraman, A., Zeithaml, V. A. \& Berry, L. L. (1988). Servqual: A multiple-item scale for measuring consumer perc. Journal of retailing, 64(1), 12.

[96] Parasuraman, A., Berry, L. \& Zeithaml, V. (2002). Refinement and reassessment of the SERVQUAL scale. Journal of retailing, 67(4), 114.

[97] Parasuraman, A., Berry, L. L. \& Zeithaml, V. A. (1993). More on improving service quality measurement. Journal of retailing, 69(1), 140-147.

[98] Parasuraman, A., Zeithaml, V. A. \& Berry, L. L. (1994). Reassessment of expectations as a comparison standard in measuring service quality: implications for further research. The Journal of Marketing, 111-124.

[99] Parasuraman, A., Zeithaml, V. A. \& Malhotra, A. (2005). ESQUAL: A multiple-item scale for assessing electronic service quality. Journal of service research, 7(3), 213-233.

[100] Paulrajan, R. \& Rajkumar, H. (2011). Service quality and customers preference of cellular mobile service providers. Journal of technology management \& innovation, 6(1), 38-45.

[101] Pretorius, D. \& Schurink, W. (2007). Enhancing service delivery in local government: the case of a district municipality. SA Journal of Human Resource Management, 5(3), 19-29.

[102] Randall, L. \& Senior, M. (1994). A model for achieving quality in hospital hotel services. International Journal of contemporary hospitality management, 6(1/2), 68-74.

[103] Reichheld, F. F. \& Sasser, J. W. (1990). Zero defections: Quality comes to services. Harvard business review, 68(5), 105-111.

[104] Robinson, L. (1999). Following the quality strategy: the reasons for the use of quality management in UK public leisure facilities. Managing leisure, 4(4), 201-217.

[105] Robinson, L. (2003). Committed to quality: the use of quality schemes in UK public leisure services. Managing Service Quality: An International Journal, 13(3), 247-255.

[106] Rowley, J. (1998). Quality measurement in the public sector: Some perspectives from the service quality literature. Total Quality Management, 9(2-3), 321-333.

[107] Turner, J. C. \& Oakes, P. J. (1986). The significance of the social identity concept for social psychology with reference to individualism, interactionism and social influence. British Journal of Social Psychology, 25(3), 237-252.

[108] Sabri, P. S. U., Ilyas, M. \& Amjad, Z. (2011). Organizational culture and its impact on the job satisfaction of the University teachers of Lahore. International Journal of Business and Social Science, 2(24).

[109] Sadek, D. M., Zainal, N. S., Taher, M. S. I. M., Yahya, A. F., Shaharudin, M. R., Noordin, N. \& Jusoff, K. (2010). Service quality perceptions between cooperative and Islamic banks of Britain. American Journal of Economics and Business Administration, 2(1), 1.

[110] Samad, S. \& Hassan, Z. (2007, July). Assessing the effects of job satisfaction and psychological contract on organizational commitment among employees in Malaysian SMEs. In The 4th SMEs IN A Global Economy Conference 2007. 
[111] Schneider, B. \& Bowen, D. E. (1985). Employee and customer perceptions of service in banks: Replication and extension. Journal of applied Psychology, 70(3), 423.

[112] Shah, S. \& Jalees, T. (2004). An analysis of job satisfaction level of faculty members at the University of Sindh. Journal of Independent studies and Research (JISR), 2(1), 26.

[113] Shammot, M. M. (2011). Quality management practices and their impact on organizational performance, and customer behavior. European Journal of Economics, Finance and Administrative Sciences, 34(2), 21-33.

[114] Sharma, J. P. \& Bajpai, N. (2010). Organizational commitment and its impact on job satisfaction of employees: A comparative study in public and private sector in India. International Bulletin of Business Administration, 9(1), 7-19.

[115] Silverthorne, C. (2004). The impact of organizational culture and person-organization fit on organizational commitment and job satisfaction in Taiwan. Leadership \& Organization Development Journal, 25(7), 592-599.

[116] Social Security System, (2011). Annual Report of Membership. Retrieved from http://www.sss.gov.ph/sss/DownloadContent?fileName=GCG_SS S_AR11.pdf

[117] Solomon, M. R., Surprenant, C., Czepiel, J. A. \& Gutman, E. G. (1985). A role theory perspective on dyadic interactions: the service encounter. The Journal of Marketing, 99-111.

[118] Sonnentag, S. \& Kruel, U. (2006). Psychological detachment from work during off-job time: The role of job stressors, job involvement, and recovery-related self-efficacy. European Journal of Work and Organizational Psychology, 15(2), 197-217.

[119] Strong, R. \& Harder, A. (2009). Implications of maintenance and motivation factors on Extension agent turnover. Journal of extension, 47(1), 1-8.

[120] Surprenant, C. F. \& Solomon, M. R. (1987). Predictability and personalization in the service encounter. The Journal of Marketing, 45(4), 86-96.

[121] Svensson, G. (2004). A customized construct of sequential service quality in service encounter chains: time, context, and performance threshold. Managing Service Quality: An International Journal, 14(6), 468-475.

[122] Svensson, G. (2006). New aspects of research into service encounters and service quality. International Journal of Service Industry Management, 17(3), 245-257.

[123] Tam, J. L. \& Wong, Y. H. (2001). Interactive selling: a dynamic framework for services. Journal of Services Marketing, 15(5), 379-396.

[124] Tamrakar, R. (2010). Impact of citizen charter in service deliver: a case of district administration office, Kathmandu.
[125] Teicher, J., Hughes, O. \& Dow, N. (2002). E-government: a new route to public sector quality. Managing Service Quality: An International Journal, 12(6), 384-393.

[126] Tjiptono, F. (2008). Service management mewujudkan layanan prima. Yogyakarta: Andi.

[127] Torres, S. A. (2017, Jan. 12). SSS, LTO, BIR, Pag-IBIG get most flak in 8888 hotlines. Retrieved from http://news.abscbn.com/news/01/12/17/sss-lto-bir-pag-ibig-get-most-flak-in8888-hotline on August 2017

[128] Uygur, A. (2009). A study into organizational commitment and job involvement: An application towards the personnel in the central organization for Ministry of Health in Turkey. Ozean Journal of Applied Science, 2(1).

[129] van Graan, J. \& Ukpere, W. I. (2012). The role of impact evaluation on service delivery within the public sector organizations. African Journal of Business Management, 6(39), 10458-10463.

[130] Wagner, C. M. (2007). Organizational commitment as a predictor variable in nursing turnover research: literature review. Journal of advanced nursing, 60(3), 235-247.

[131] Wisniewski, M. (1996). Measuring service quality in the public sector: the potential for SERVQUAL. Total Quality Management, 7(4), 357-366.

[132] Wisniewski, M. (2001). Using SERVQUAL to assess customer satisfaction with public sector services. Managing Service Quality: An International Journal, 11(6), 380-388.

[133] Yang, Z. \& Fang, X. (2004). Online service quality dimensions and their relationships with satisfaction: A content analysis of customer reviews of securities brokerage services. International Journal of Service Industry Management, 15(3), 302-326.

[134] Zamil, A. M. \& Shammot, M. M. (2011). Role of measuring customer satisfaction in improving the performance in the public sector organization. Journal of Business Studies Quarterly, 2(3), 32.

[135] Zammuto, R. F., Keaveney, S. M. \& O'Connor, E. J. (1996). Rethinking student services: assessing and improving service quality. Journal of Marketing for Higher Education, 7(1), 45-70.

[136] Zeithaml, G. (2007). Organizational citizenship behavior: Construct redefinition, operationalization and validation. Academy of Management Journal, 5(8) 37-52.

[137] Zeithaml, V. A., Parasuraman, A., Berry, L. L. \& Berry, L. L. (1990). Delivering quality service: Balancing customer perceptions and expectations. The Free Press, New York.

[138] Zeithaml, V. A., Berry, L. L. \& Parasuraman, A. (1996). The behavioral consequences of service quality. The Journal of Marketing, 31-46.

[139] Zeithaml, V. A., Bitner, M. J. \& Gremler, D. D. (1996). Services Marketing McGraw Hill. New York. 